\title{
Effect of combination of light and drought stress on physiology and oxidative metabolism of rice plants
}

\author{
Atreyee Chatterjee ${ }^{1}$, Tanmay Dey ${ }^{1}$, Gábor Galiba ${ }^{2}$, Gábor Kocsy ${ }^{2}$, Narottam Dey ${ }^{3} \&$ Rup Kumar Kar $^{1^{*}}$ \\ ${ }^{1}$ Department of Botany, Visva-Bharati, Santiniketan 731 235, West Bengal, India \\ ${ }^{2}$ Agricultural Institute, Centre for Agricultural Research, Martonvásár, Hungary \\ ${ }^{3}$ Department of Biotechnology, Visva-Bharati, Santiniketan 731 235, West Bengal, India \\ *Email: rupkumar.kar@visva-bharati.ac.in
}

\section{ARTICLE HISTORY}

Received: 03 May 2021

Accepted: 02 July 2021

Available online: 19 August 2021

\section{KEYWORDS}

Antioxidant enzymes

Drought

Oxidative stress

Light

Rice

ROS production

\section{ABSTRACT}

The realized productivity of crop plants is generally lower than the potential productivity due to the influence of one or more external stresses (biotic and abiotic). Simultaneous occurrence of combination of abiotic stresses, which is more common under field condition, results in compounded effect on functional processes. Main focus of the present work is the combined effect of drought and light (irradiance) on rice plants. Potted seedlings of four selected rice lines (viz., IR36, N22, CRD40 and Bhootmuri) were exposed to three different levels of drought stress $(50 \%, 25 \%, 12.5 \%$ of water) along with control (100\%) in combination with three different light intensities (high, medium and low) during experimental period. After 7 days of stress, plant height and relative water content (RWC) were relatively low while root length increased with increasing water stress level and light intensity. Protein content increased with increasing water stress and light intensity, while chlorophyll level was higher at higher light intensities. Malondialdehyde (MDA) content, indicative of lipid peroxidation, increased with water stress only at high light intensities. Superoxide dismutase (SOD), peroxidase (POX) and ascorbate peroxidase (APX) activities increased with combined drought and light stress level, whereas catalase (CAT) activity was higher at higher light intensities. On the other hand, superoxide $\left(\mathrm{O}_{2}{ }^{-}\right)$ production, but not hydrogen peroxide $\left(\mathrm{H}_{2} \mathrm{O}_{2}\right)$ production was higher with increasing water stress and light intensity. It appears that light-induced $\operatorname{ROS}\left(\mathrm{O}_{2}{ }^{-}\right)$production under drought condition provoked oxidative stress, though a potential mechanism of tolerance was apparent through antioxidant system.

\section{Introduction}

Recent issues of global warming and associated climate errors have been a big alert for crop plants, which are increasingly subjected to different biotic and abiotic stresses and their combinations affecting growth and yield (1-4). In nature, plants are always likely to be exposed to different types of abiotic stresses viz. drought, flooding, salinity, heat, cold and others (5-8). However, under field conditions, stresses may often occur in combinations, like drought along with heat or high light intensity, conditions which are very common to most of the crop growing areas, particularly in India. Interestingly, impact of such combinations may not always be additive, depending on the nature of interacting stresses (3, 9-13). Rather, some new responses may become apparent because of stress combination, besides those that appear commonly in response to individual stresses. A stress matrix has been developed considering the responses of plants due to interactions among different stresses reflecting both the negative and positive impacts on plant growth and development $(1,14)$.

Rice is one of the most important food crops, consumed by almost half of the world's human population and it is one of those few plants, of which every part is used, nothing is discarded. Drought is most threatening abiotic stress that reduces rice production globally (15) because rice needs huge amount of water for its growth and development. In addition, most often crop plants growing in drought hit areas may encounter other stresses (e.g. heat, light, salinity) in combination with drought $(16,17)$.

A plethora of research has been done on responses of crop plants individually to drought and light (irradiance), and the effect of drought combined with heat or salinity, but a little attention has been paid so far to the combined effect of drought and light on rice plants. Actually in India, drought is very common and in combination with bright sunlight it becomes more stressful for plants. Present work is mainly focused on combined effect of drought and

(c) Chatterjee et al. (2021). This is an open-access article distributed under the terms of the Creative Commons Attribution License, which permits unrestricted use, distribution and reproduction in any medium, provided the original author and source are credited (https://creativecommons.org/licenses/by/4.0/). 
light (irradiance) on rice plants as reflected in different physiological and biochemical traits including oxidative metabolism.

\section{Materials and Methods}

\section{Plant material, growth condition and induction of stress}

Four rice lines were selected for this study viz. IR36, N22, CRD40 and Bhootmuri, of which IR36 is a popular high yielding rice variety, N22 and CRD40 are two drought tolerant lines and Bhootmuri is a traditional rice variety of West Bengal (India). Seven day old seedlings were raised after germinating seeds on moist cotton pad in Petri dishes and then transferred to small pots containing equal mix of autoclaved natural soil and soilrite. Pots were maintained in a Plant Growth Chamber (Weisstechnik, Germany) under three regimes of photon flux densities (Low- $20 \mu$ moles $\mathrm{m}^{-2} \mathrm{~s}^{-1}$, Medium- $154 \mu$ moles $\mathrm{m}^{-2} \mathrm{~s}^{-1}$, High- $266 \mu$ moles $\mathrm{m}^{-2} \mathrm{~s}^{-1}$ ) in combination with four levels of water status (Control - 100\%, S1 - 50\%, S2 - 25\%, S3 - 12.5\% by manipulating application of water). Humidity was maintained at $70 \%$ while daily temperature cycle was $30^{\circ} / 26{ }^{\circ} \mathrm{C}$ (day/night). After 4 days of establishment period and 7 days of stress period, 18 days old seedlings were subjected to physiological and biochemical analyses for assessment of stress responses.

\section{Physiological studies}

Different physiological parameters such as plant height $(\mathrm{cm})$ and root length $(\mathrm{cm})$, supported by representative photographs and relative water content (RWC \%), indicative of plant water status, were studied. RWC of the leaves were calculated by the following formula (18):

\section{RWC $(\%)=(F W-D W / T W-D W) \times 100$}

(Where, FW- Fresh Weight, DW- Dry Weight, TWTurgid Weight).

\section{Biochemical analyses}

\section{Total chlorophyll and protein content}

Content of total chlorophyll was determined spectrophotometrically following the standard method (19). After extraction of the leaf tissues with acetone $(80 \%)$ absorbance of the supernatant was read at $645 \mathrm{~nm}$ and $663 \mathrm{~nm}$ with a UV- Vis spectrophotometer (Systronics, India) and the total chlorophyll content was calculated using the formula:

Content of total chlorophyll (mg/g tissue) =

$$
20.2\left(\mathrm{~A}_{645}\right)+8.02\left(\mathrm{~A}_{663}\right) \times \mathrm{V} /(1000 \times \mathrm{W})
$$

[where, $\mathrm{A}_{645}$ and $\mathrm{A}_{663}-$ absorbance at $645 \mathrm{~nm}$ and 663 $\mathrm{nm}$, respectively, $\mathrm{V}=$ total volume used $(\mathrm{ml}), \mathrm{W}$ amount of plant materials taken (g)].

Total soluble protein content was measured from the above pellets after chlorophyll extraction according to the standard methods using Folin phenol reagent (20).

\section{Malondialdehyde (MDA) content}

MDA, a product of polyunsaturated fatty acid peroxidation in plants, was quantified in leaf tissues following the method (21) with some modifications. Leaves were homogenized in $0.1 \%$ (w/v) trichloroacetic acid (TCA) and centrifuged at 12000 rpm for $15 \mathrm{~min}$ at $4{ }^{\circ} \mathrm{C}$. Supernatant was then mixed with $20 \%$ TCA containing $0.5 \%$ thiobarbituric acid (TBA), which was incubated at $95^{\circ} \mathrm{C}$ for $25 \mathrm{~min}$. Then, the reaction was stopped by cooling on ice and absorbance was read at $535 \mathrm{~nm}$ and $600 \mathrm{~nm}$. MDA concentration was determined with an extinction coefficient $\varepsilon^{\mathrm{M}}=155 \mathrm{mM}^{-1} \mathrm{~cm}^{-1}$ and the content was expressed as $\mu \mathrm{M} \mathrm{g}^{-1}$ tissue.

\section{Antioxidant enzymes}

Activities of four important antioxidant enzymes viz., superoxide dismutase, catalase, peroxidase and ascorbate peroxidase were studied.

\section{Superoxide dismutase (SOD, EC 1.15.1.1)}

SOD enzyme activity was determined (22). Leaf sample was homogenized with potassium phosphate buffer (pH 7.8) and centrifuged twice at $7000 \mathrm{rpm}(5$ $\mathrm{min}$ ) and $12000 \mathrm{rpm}$ (20 $\mathrm{min})$. The supernatant was then used as crude enzyme extract. Enzyme extract was reacted with a mixture of $1.3 \mu \mathrm{M}$ riboflavin, 13 $\mu \mathrm{M}$ methionine, $0.05 \mathrm{M}$ sodium carbonate and $63 \mu \mathrm{M}$ NBT under illumination (white fluorescent lamps) for 30 min. A similar set was run in the dark as a control. Absorbance was read at $560 \mathrm{~nm}$ by a UV-Vis spectrophotometer (Systronics, India).

\section{Catalase, Peroxidase, Ascorbate peroxidase (CAT, POX and APX)}

Enzymes were extracted from leaf samples by homogenizing in cold $0.05 \mathrm{M}$ phosphate citrate buffer (pH 6.0) followed by centrifugation at $5000 \mathrm{rpm}$ for $10 \mathrm{~min}$ at $4{ }^{\circ} \mathrm{C}$. The supernatant was used as crude enzyme source.

\section{Assay for CAT activity}

CAT activity (EC 1.11.1.6) was determined following the method (23). The active set was prepared by adding $\mathrm{H}_{2} \mathrm{O}_{2}(4.5 \mathrm{mM})$ to the same amount of diluted enzyme extract and then incubated at $37{ }^{\circ} \mathrm{C}$ for $5 \mathrm{~min}$. The reaction was terminated by adding $0.8 \%$ titanium sulphate $\left[\mathrm{Ti}\left(\mathrm{SO}_{4}\right)_{2}\right]$. In case of the inactive set, enzyme extract was pre-killed by adding $0.8 \%$ titanium sulphate before reacting with $\mathrm{H}_{2} \mathrm{O}_{2}$. Absorbance was read at $420 \mathrm{~nm}$.

\section{Assay for POX and APX activity}

For the assay of POX activity (EC 1.11.1.7) enzyme extract was incubated with $50 \mathrm{mM}$ phosphate buffer ( $\mathrm{pH} 6.8), \mathrm{H}_{2} \mathrm{O}_{2}$ (25 mM), pyrogallol (15 mM) for $2 \mathrm{~min}$ at $25^{\circ} \mathrm{C}$. The reaction was terminated by adding $5 \% \quad \mathrm{H}_{2} \mathrm{SO}_{4}$. Activity was determined by quantifying the amount of purpurogallin, the product of pyrogallol oxidation by measuring absorbance at $430 \mathrm{~nm}$ following the method (24). For APX assay (EC 1.11.1.11), the same procedure was followed except using ascorbate $(0.5 \mathrm{mM})$ as the substrate in place of pyrogallol. Absorbance was read at $265 \mathrm{~nm}$ by a UV-Vis spectrophotometer (25). 


\section{Enzyme activity}

For all the four antioxidant enzymes, activity was determined by the standard formula (26): $(\Delta \mathrm{A} \times$ $\mathrm{T}) /(\mathrm{t} \times \mathrm{V} \times \mathrm{w})$ where, $\Delta \mathrm{A}=$ Absorbance active Absorbance inactive, $\mathrm{T}=$ total volume of enzyme extract, $\mathrm{t}=$ time of incubation, $\mathrm{v}=$ volume of enzyme in the reaction, $\mathrm{w}=$ weight of the leaf tissue.

\section{Estimation of total superoxide $\left(\mathrm{O}_{2}^{-}\right)$}

Total $\mathrm{O}_{2}-$ production in the leaves was measured spectrophotometrically following the method (27) with little modifications. Leaf samples were homogenized in $0.5 \mathrm{mM}$ epinephrine solution and incubated in a shaker (REMI CM-101 PLUS) for 45 min at room temperature under dark condition. Then the samples were centrifuged for $10 \mathrm{~min}$ at $5000 \mathrm{rpm}$ and the absorbance of the supernatants was measured at $480 \mathrm{~nm}$ by UV-VIS Spectrophotometer (Systronics, India). $\mathrm{O}_{2}$ production was calculated using an extinction coefficient of $4020 \mathrm{M}^{-1} \mathrm{~cm}^{-1}$ and expressed as $\mu \mathrm{M} \mathrm{g}^{-1}$ tissue.

\section{Estimation of total hydrogen peroxide $\left(\mathrm{H}_{2} \mathrm{O}_{2}\right)$}

Total $\mathrm{H}_{2} \mathrm{O}_{2}$ production of rice leaves was estimated using the xylenol orange assay following the method (28) with little modifications. The assay mixture was prepared by using two reagents, 1 part of reagent A [containing $25 \mathrm{mM} \mathrm{FeSO}_{4}, 25 \mathrm{mM}$ $\left(\mathrm{NH}_{4}\right)_{2} \mathrm{SO}_{4}$ and $\left.2.5 \mathrm{M} \mathrm{H}_{2} \mathrm{SO}_{4}\right]$ and 100 parts of reagent $\mathrm{B}$ (containing $125 \mu \mathrm{M}$ xylenol orange and $100 \mathrm{mM}$ sorbitol) which was mixed and stirred for 15 min. Weighed leaf samples were homogenized in the above assay mixture and then shaken for 90 min in a shaker (REMI CM-101 PLUS) at room temperature under dark condition. Then, the samples were centrifuged at $5000 \mathrm{rpm}$ for $10 \mathrm{~min}$ and the absorbance of the supernatants was measured at $560 \mathrm{~nm}$ by UV-VIS Spectrophotometer (Systronics, India). $\mathrm{H}_{2} \mathrm{O}_{2}$ production was calculated using a standard curve with known concentrations of $\mathrm{H}_{2} \mathrm{O}_{2}$ and expressed as $\mathrm{ng} \mathrm{g} \mathrm{g}^{-1}$ tissue $\mathrm{min}^{-1}$.

\section{Statistical analyses}

All the experimental data are presented as means of three replicates, except shoot and root growth analysis where ten replicates were taken and standard error around mean was shown as vertical bar in the figures. Two way ANOVA with interactions were performed using R (open source statistical software) to determine statistical significance of the experimental data at $p<0.05$ level.

\section{Results}

Among the physiological parameters, shoot growth studies showed that at low light intensity plant height was relatively lower and did not vary much with increasing water stress in case of all varieties, as revealed by photographs (Fig. 1) as well as measurements (Fig. 4). However, at medium and high light intensities plant height declined significantly with increasing level of water stress in all the varieties and such reduction in plant height was more severe at high light intensity (Fig. 2-4). Considering only light intensity, shoot growth increased with increasing light intensity except for S3, although increase was less at high light intensity. Among the four selected varieties, Bhootmuri maintained maximum plant height. On the other hand, root growth, as depicted by the photographs (Fig. 5-7) and bar graph (Fig. 8) proportionately increased with higher drought stress more prominently in IR36 and again root growth was more at higher intensities of light. RWC, indicative of water status, of leaves decreased much with increasing drought stress in case of all varieties and increased light intensity caused further decline in RWC under water stress (Fig. 9).

Overall content of total chlorophyll was relatively very low at low light intensity except in N22 variety, while it was maximum at medium light (in case of Bhootmuri) or both medium and high light intensities (in all other varieties) (Fig. 10). On the other hand, with increasing level of water stress chlorophyll content of leaves increased till S2 level (25\% water content) except at low light in case of all varieties. N22 variety showed highest amount of chlorophyll content even at the extreme level of combination stress. Similarly, amount of total protein was also minimum at low light, but became higher at medium light intensity while it was somewhat lower again at high light intensity except in N22 variety (Fig. 11). With increasing water stress, however, protein content increased, increase being maximum at S3 level (12.5\% water status) in case of all varieties.

Lipid peroxidation, one of the major effects of water stress as a consequence of oxidative metabolism (through production of ROS), is indicated by MDA content. There was little change in MDA content that increased only marginally with light intensity and increasing level of water stress except in S3 plants exposed to highest level of stress $(12.5 \%$ water status) at high light where the content shoot up to almost 2-3 times (Fig. 12).

Among the antioxidant enzymes, SOD is considered as the first line of defence. Here, in case of all the varieties SOD activity showed an increase, though marginally in CRD40, with increasing light intensity (Fig. 13). In case of S1 plants $(50 \%$ of water) and S2 plants (25\% of water) but not in S3 plants $(12.5 \%$ of water) activity became lower than control particularly at low light. At medium and high light intensity SOD activity was more or less unchanged with water stress. In case of CAT, overall activity was very low at low intensity of light compared to that of plants grown at medium and high light intensity (Fig. 14). However, water stress has differential effect on such activity at different light intensity. Thus, at medium light, activity increased to maximum at S1 level (CRD40 variety) or S2 level (N22 variety) except in Bhootmuri where activity was lower than control at S1 and S2 level while it was highest at S3 level. At high light, CAT activity more or less increased with increasing water stress. 

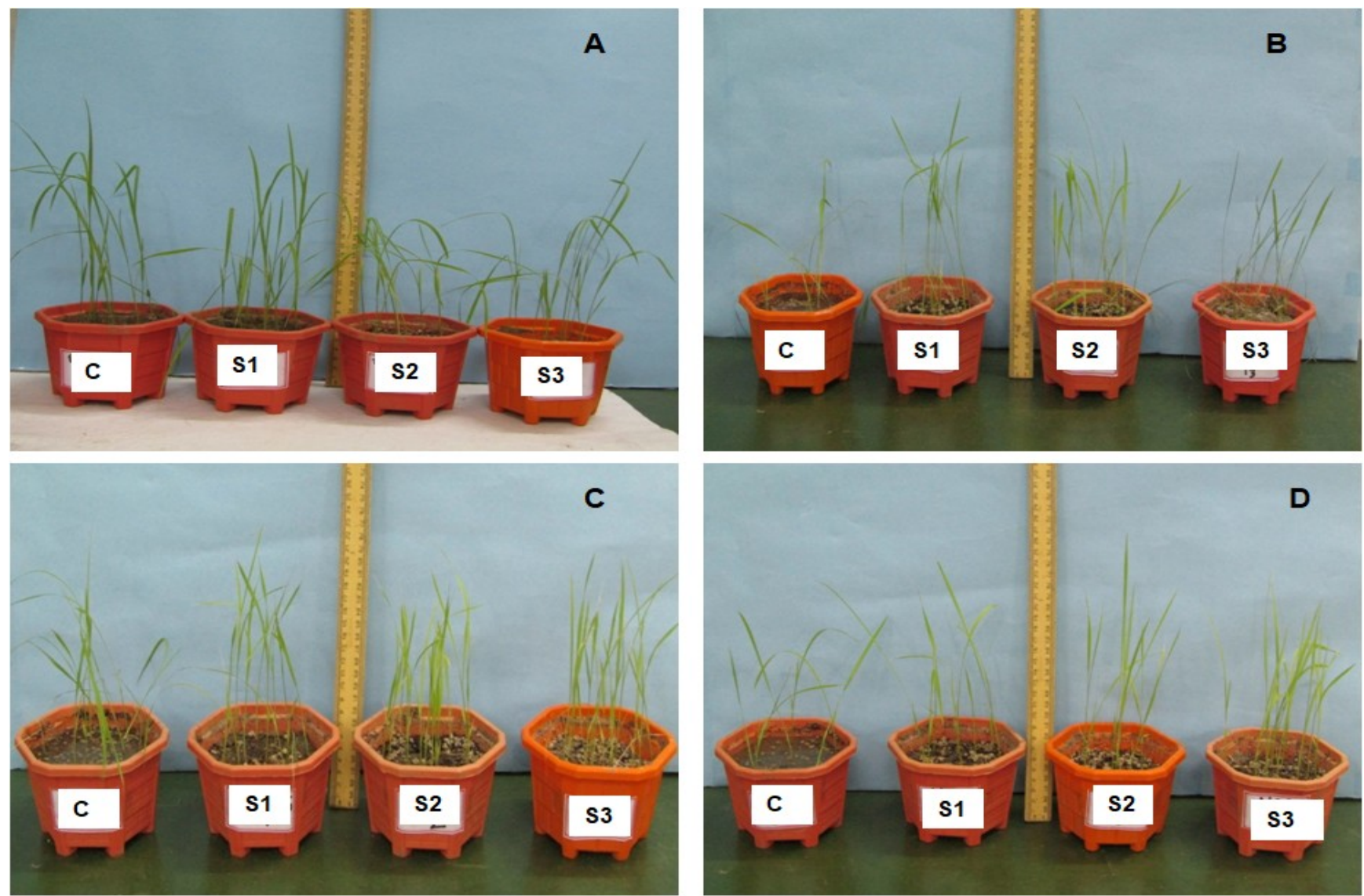

Fig. 1. Photographs of representative plants showing changes in shoot length in response to combination of low light intensity ( $20 \mu$ moles $\mathrm{m}^{-2} \mathrm{~s}^{-1}$ ) and different water stress levels [Control (C, 100\%), S1 (50\%), S2 (25\%), S3 (12.5\% )] in 4 rice varieties - Bhootmuri (A), CRD 40 (B), IR36 (C) and N22 (D).
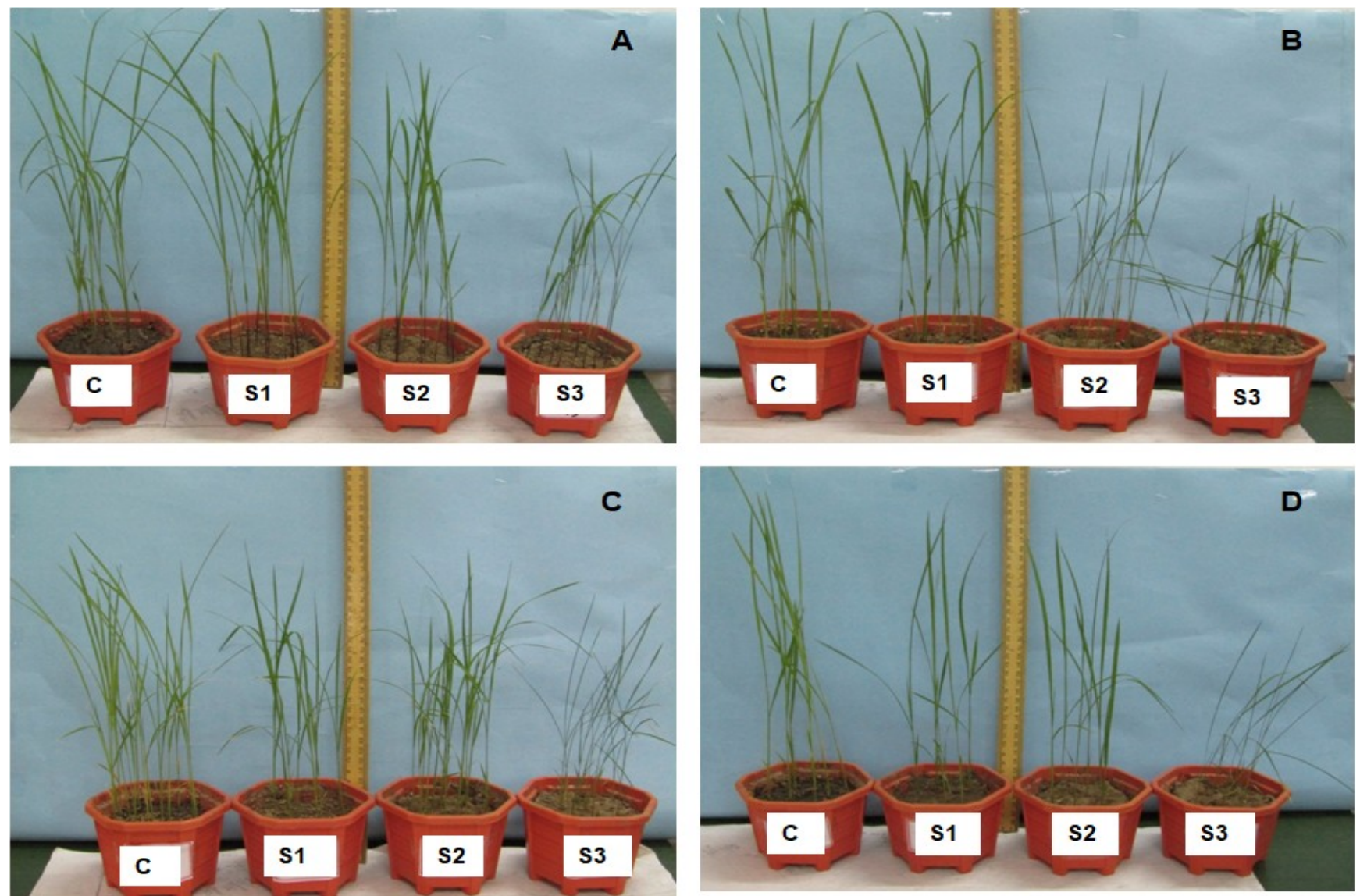

Fig. 2. Photographs of representative plants showing changes in shoot length in response to combination of medium light intensity (154 $\mu$ moles $\mathrm{m}^{-2} \mathrm{~s}^{-1}$ ) and different water stress levels [Control (C, 100\%), S1 (50\%), S2 (25\%), S3 (12.5\%)] in 4 rice varieties - Bhootmuri (A), CRD 40 (B), IR36 (C) and N22 (D). 

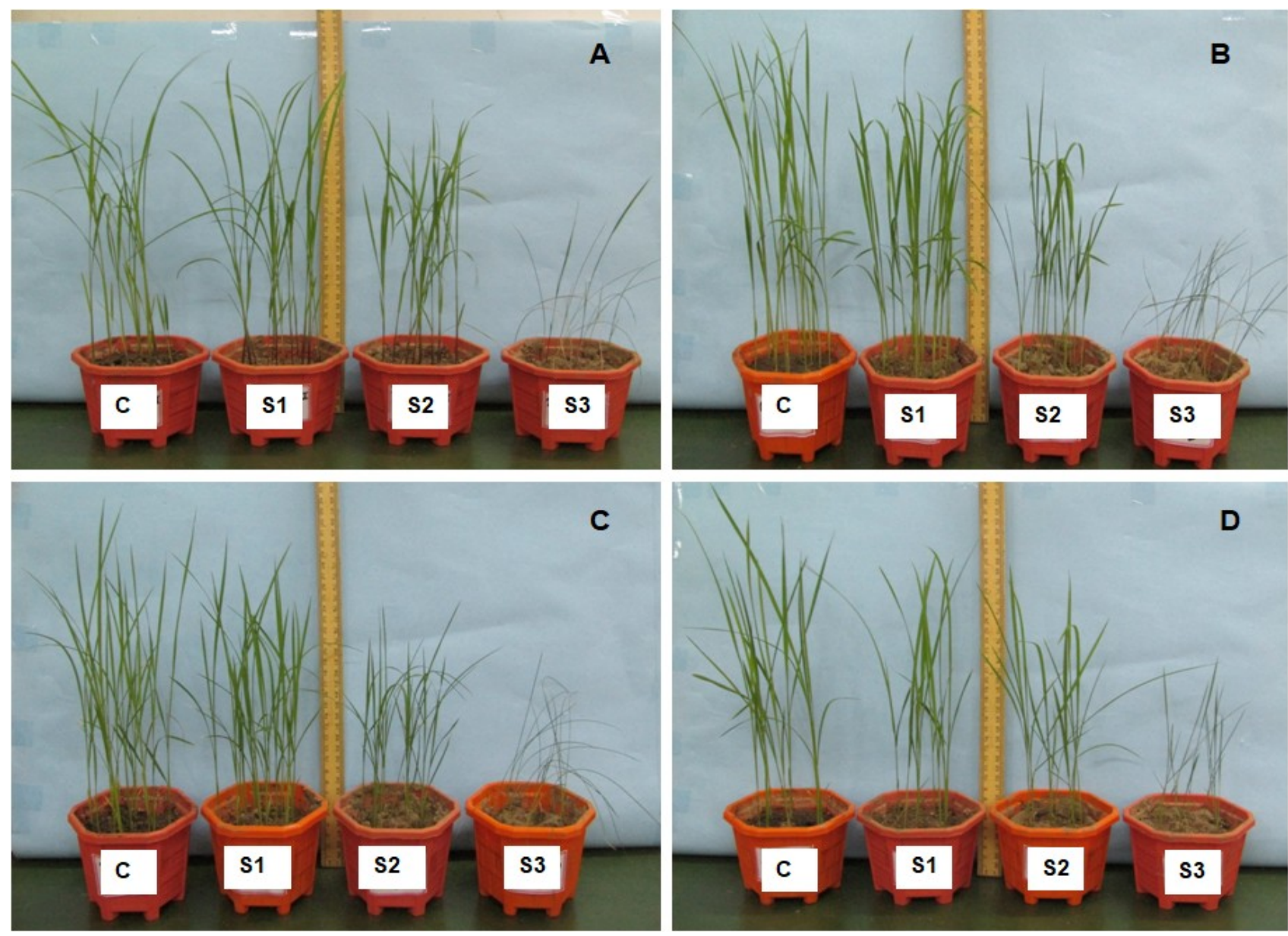

Fig. 3. Photographs of representative plants showing changes in shoot length in response to combination of high light intensity (266 $\mu$ moles $\mathrm{m}^{-2} \mathrm{~s}^{-1}$ ) and different water stress levels [Control (C, 100\%), S1 (50\%), S2 (25\%), S3 (12.5\%)] in 4 rice varieties - Bhootmuri (A), CRD 40 (B), IR36 (C) and N22 (D).
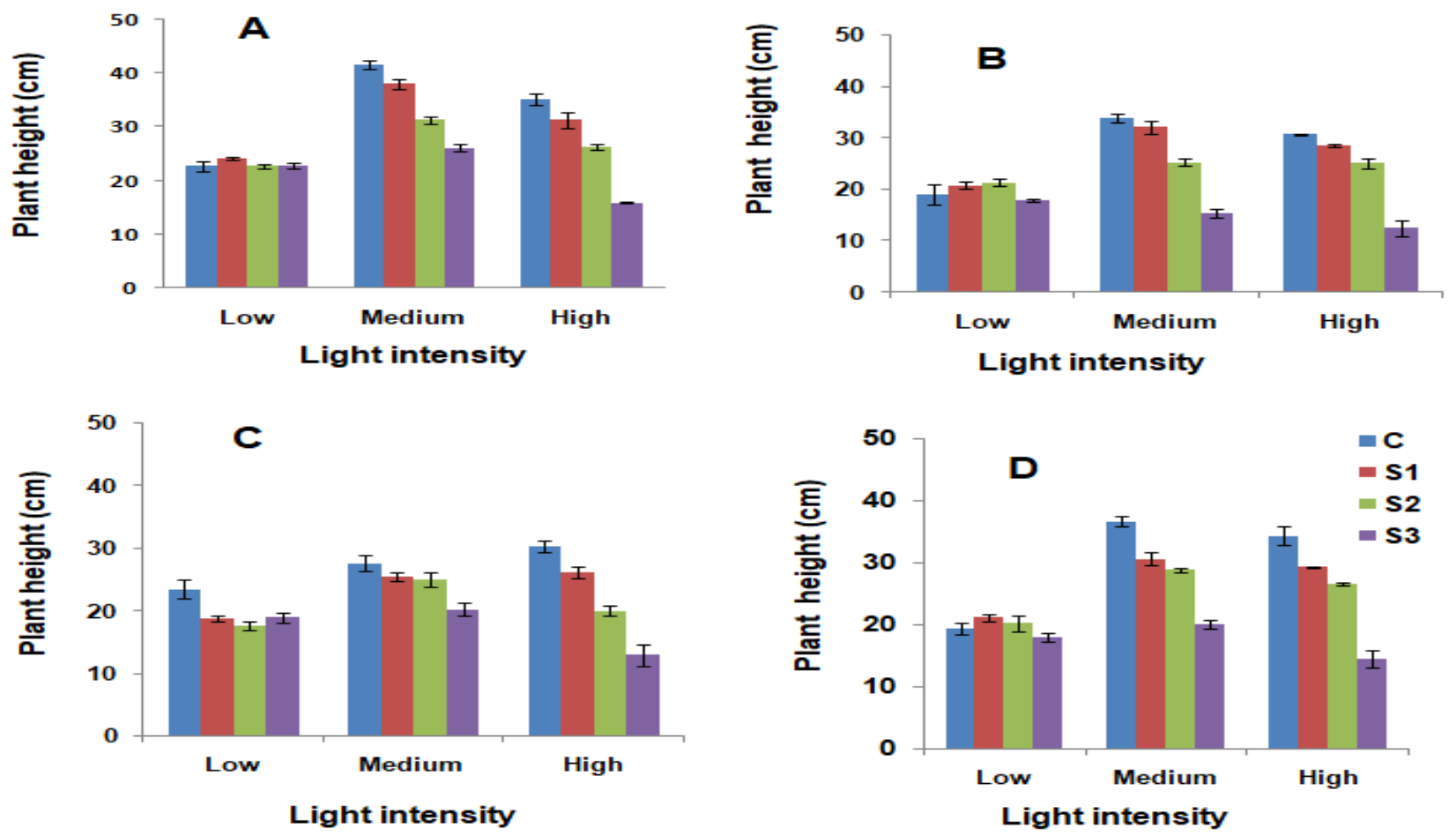

Fig. 4. Changes in plant height in response to combination of different light intensities [Low $\left(20 \mu \mathrm{moles} \mathrm{m}^{-2} \mathrm{~s}^{-1}\right) \mathrm{Medium}\left(154 \mu \mathrm{moles} \mathrm{m}^{-2} \mathrm{~s}^{-1}\right)$, High (266 $\mu$ moles $\left.\mathrm{m}^{-2} \mathrm{~s}^{-1}\right)$ ] and water stress levels [Control (C, 100\%), S1 (50\%), S2 (25\%), S3 (12.5\% )] in 4 rice varieties - Bhootmuri (A), CRD 40 (B), IR36 (C) and N22 (D). Vertical bars represent \pm SE. 


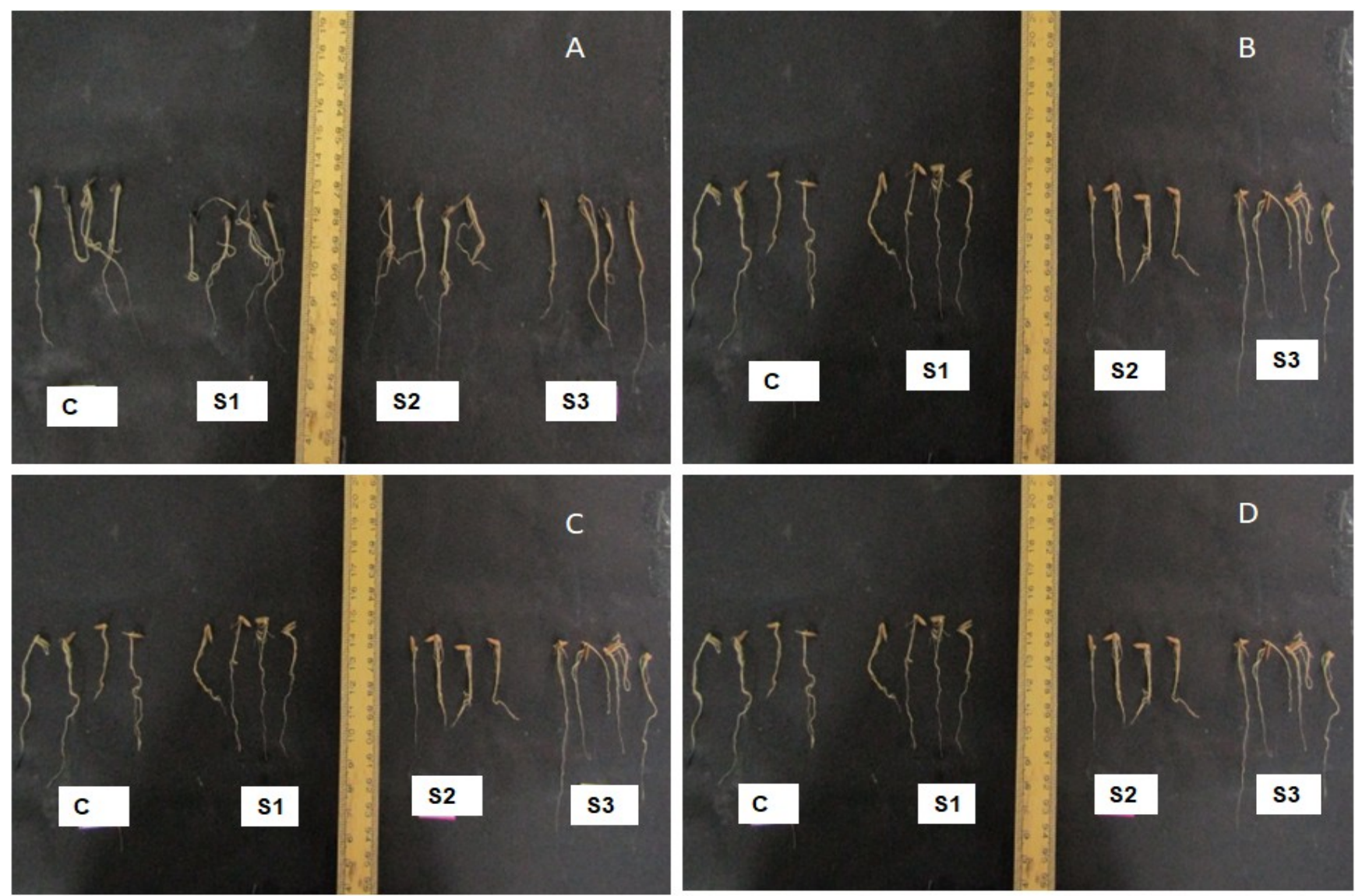

Fig. 5. Photographs of root portions from representative plants showing changes in root length in response to combination of low light intensity ( $20 \mu$ moles $\mathrm{m}^{-2} \mathrm{~s}^{-1}$ ) and different water stress levels [Control (C, 100\%), S1 (50\%), S2 (25\%), S3 (12.5\% )] in 4 rice varieties -

Bhootmuri (A), CRD 40 (B), IR36 (C) and N22 (D).

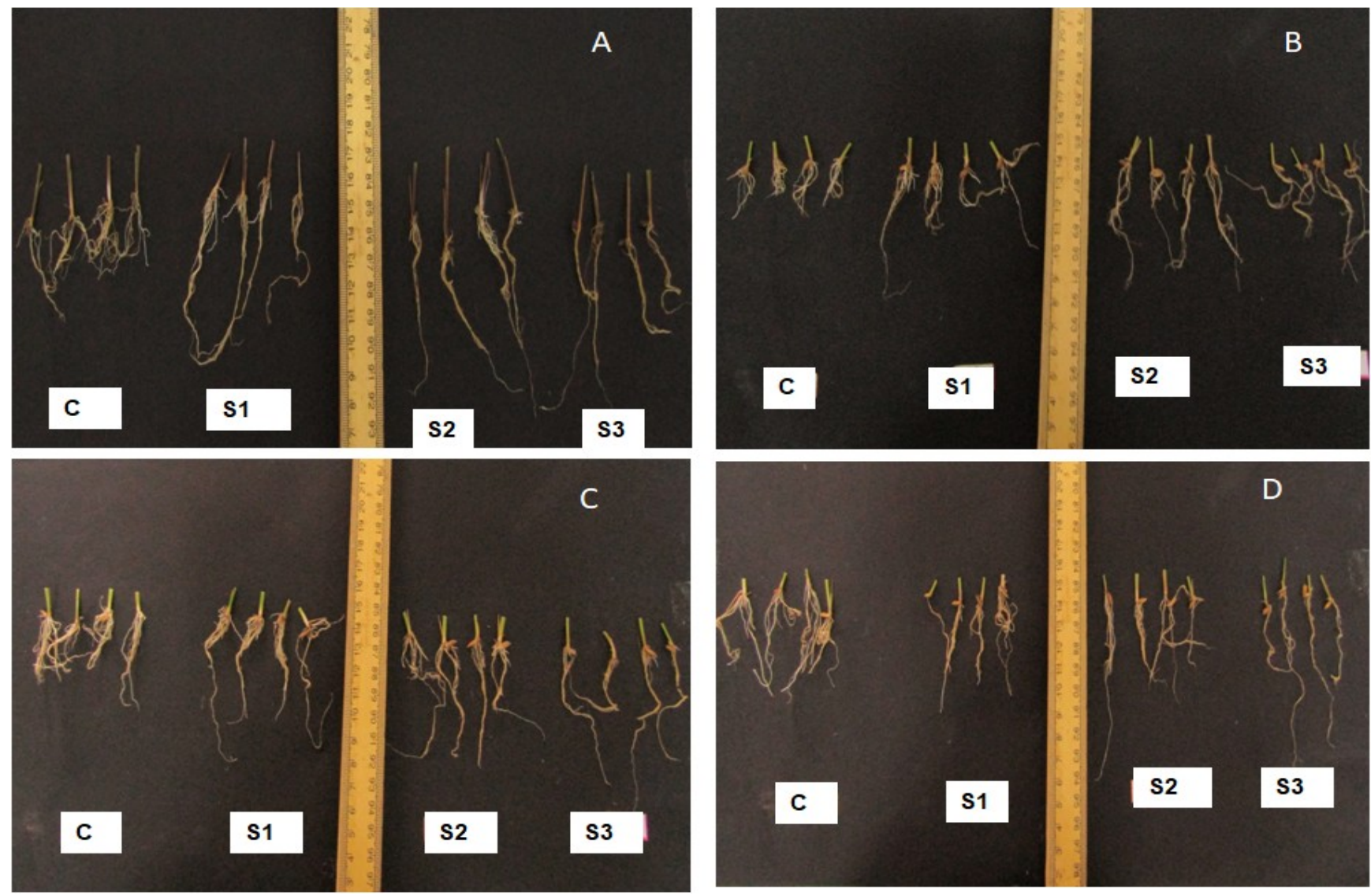

Fig. 6. Photographs of root portions from representative plants showing changes in root length in response to combination of medium light intensity ( $154 \mu$ moles $\mathrm{m}^{-2} \mathrm{~s}^{-1}$ ) and different water stress levels [Control (C, 100\%), S1 (50\%), S2 (25\%), S3 (12.5\% )] in 4 rice varieties Bhootmuri (A), CRD 40 (B), IR36 (C) and N22 (D). 

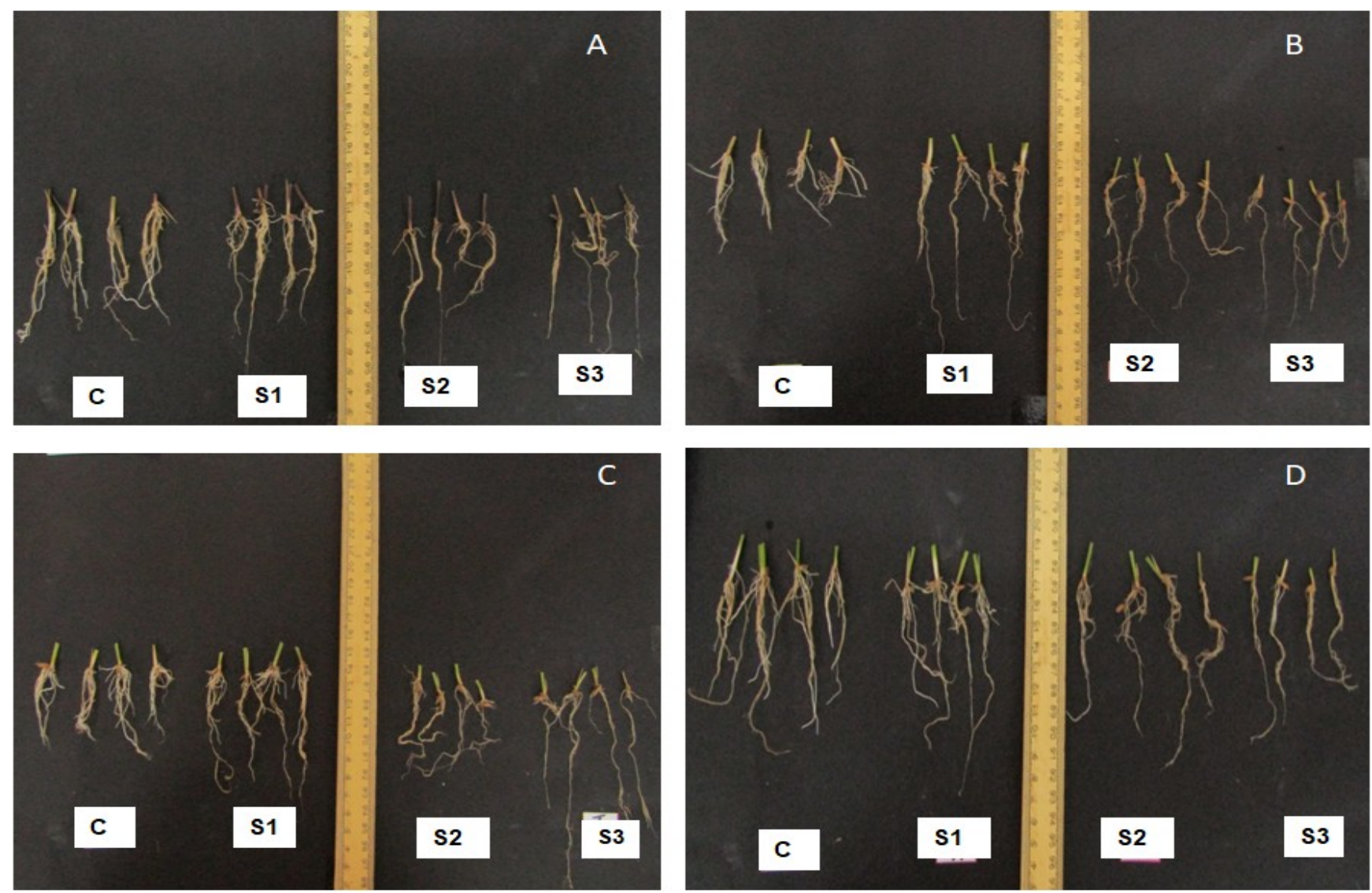

Fig. 7. Photographs of root portions from representative plants showing changes in root length in response to combination of high light intensity ( $266 \mu$ moles $\mathrm{m}^{-2} \mathrm{~s}^{-1}$ ) and different water stress levels [Control (C, 100\%), S1 (50\%), S2 (25\%), S3 (12.5\% )] in 4 rice varieties Bhootmuri (A), CRD 40 (B), IR36 (C) and N22 (D).
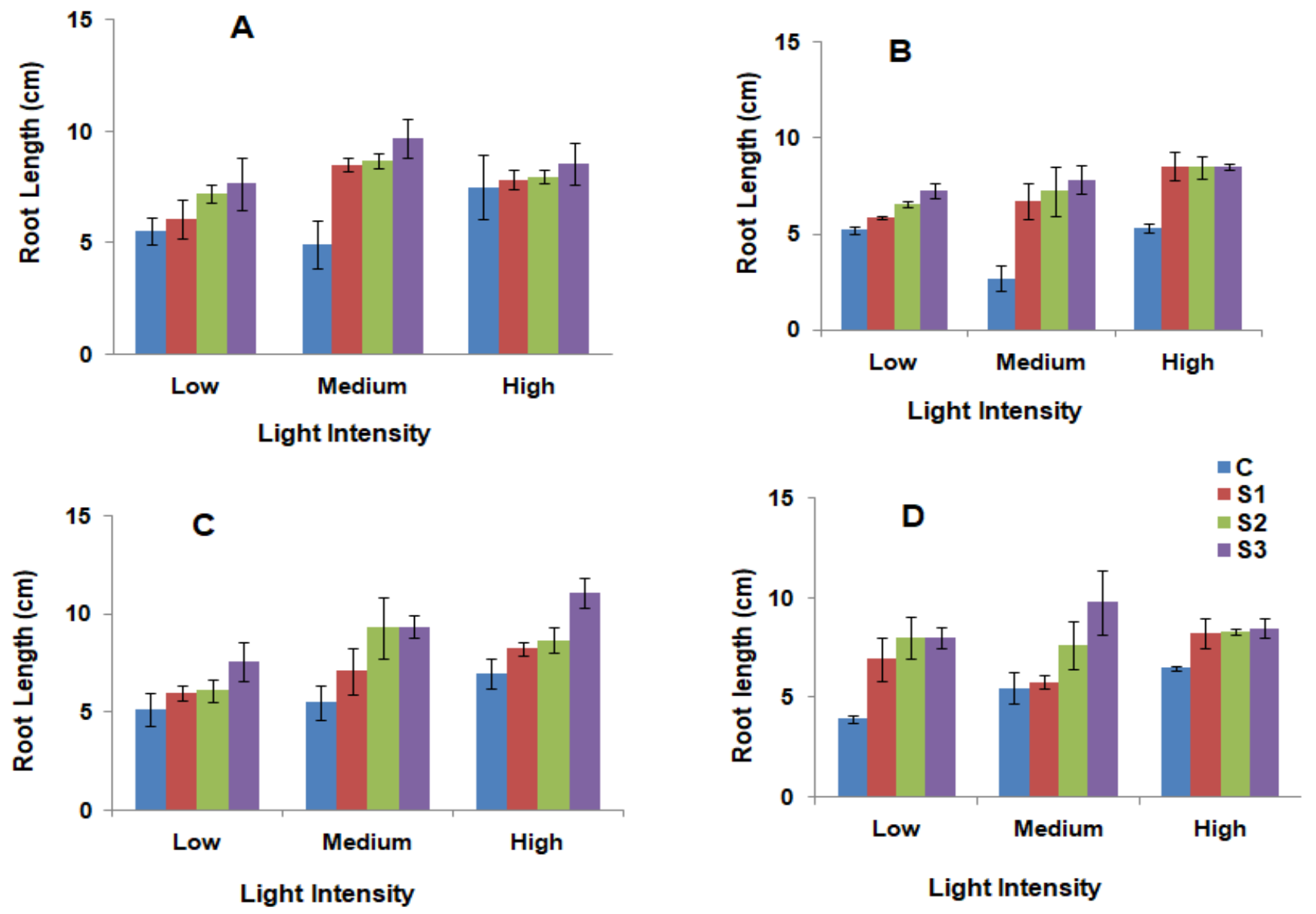

Fig. 8. Changes in root length in response to combination of different light intensities [Low $\left(20 \mu\right.$ moles $\left.\mathrm{m}^{-2} \mathrm{~s}^{-1}\right)$ Medium $\left(154 \mu \mathrm{moles} \mathrm{m}^{-2} \mathrm{~s}^{-1}\right)$, High $\left(266 \mu\right.$ moles $\left.\mathrm{m}^{-2} \mathrm{~s}^{-1}\right)$ ] and water stress levels [Control (C, 100\%), S1 (50\%), S2 (25\%), S3 (12.5\% )] in 4 rice varieties - Bhootmuri (A), CRD 40 (B), IR36 (C) and N22 (D).Vertical bars represent \pm SE. 


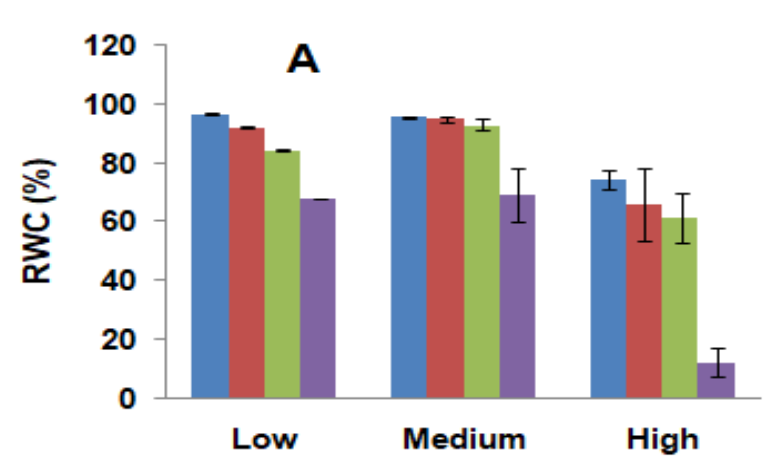

Light Intensity

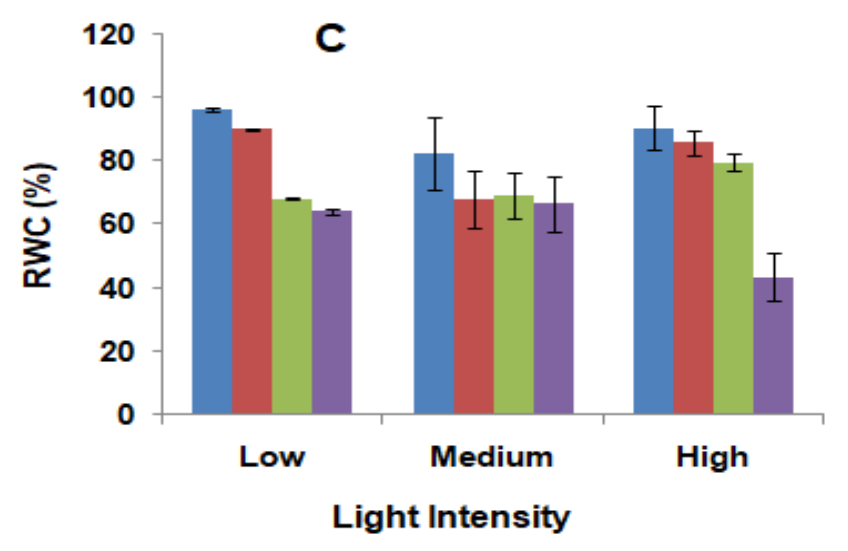

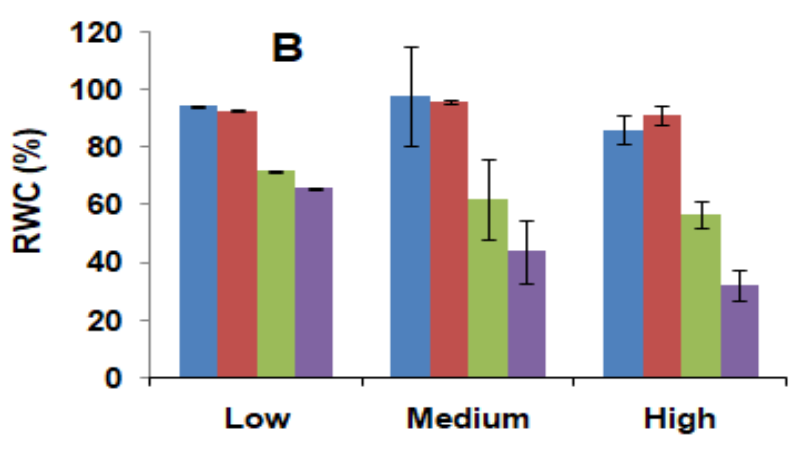

Light Intensity

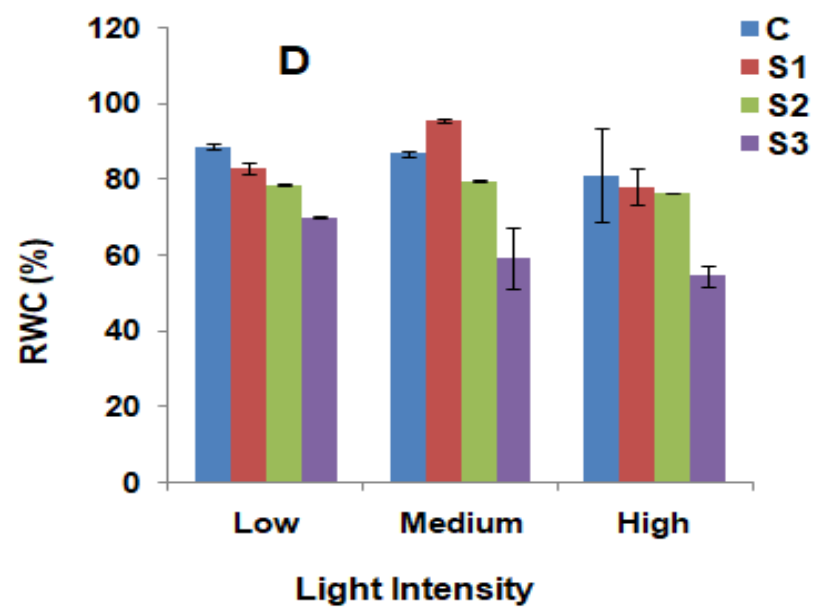

Fig. 9. Changes in relative water content (RWC) in response to combination of different light intensities [Low $\left(20 \mu \mathrm{moles}^{-2} \mathrm{~s}^{-1}\right) \mathrm{Medium}$ $\left(154 \mu\right.$ moles $\left.\mathrm{m}^{-2} \mathrm{~s}^{-1}\right)$, High $\left(266 \mu\right.$ moles $\left.\mathrm{m}^{-2} \mathrm{~s}^{-1}\right)$ ] and water stress levels [Control $(\mathrm{C}, 100 \%)$, S1 (50\%), S2 (25\%), S3 (12.5\% )] in 4 rice varieties Bhootmuri (A), CRD 40 (B), IR36 (C) and N22 (D). Vertical bars represent \pm SE.
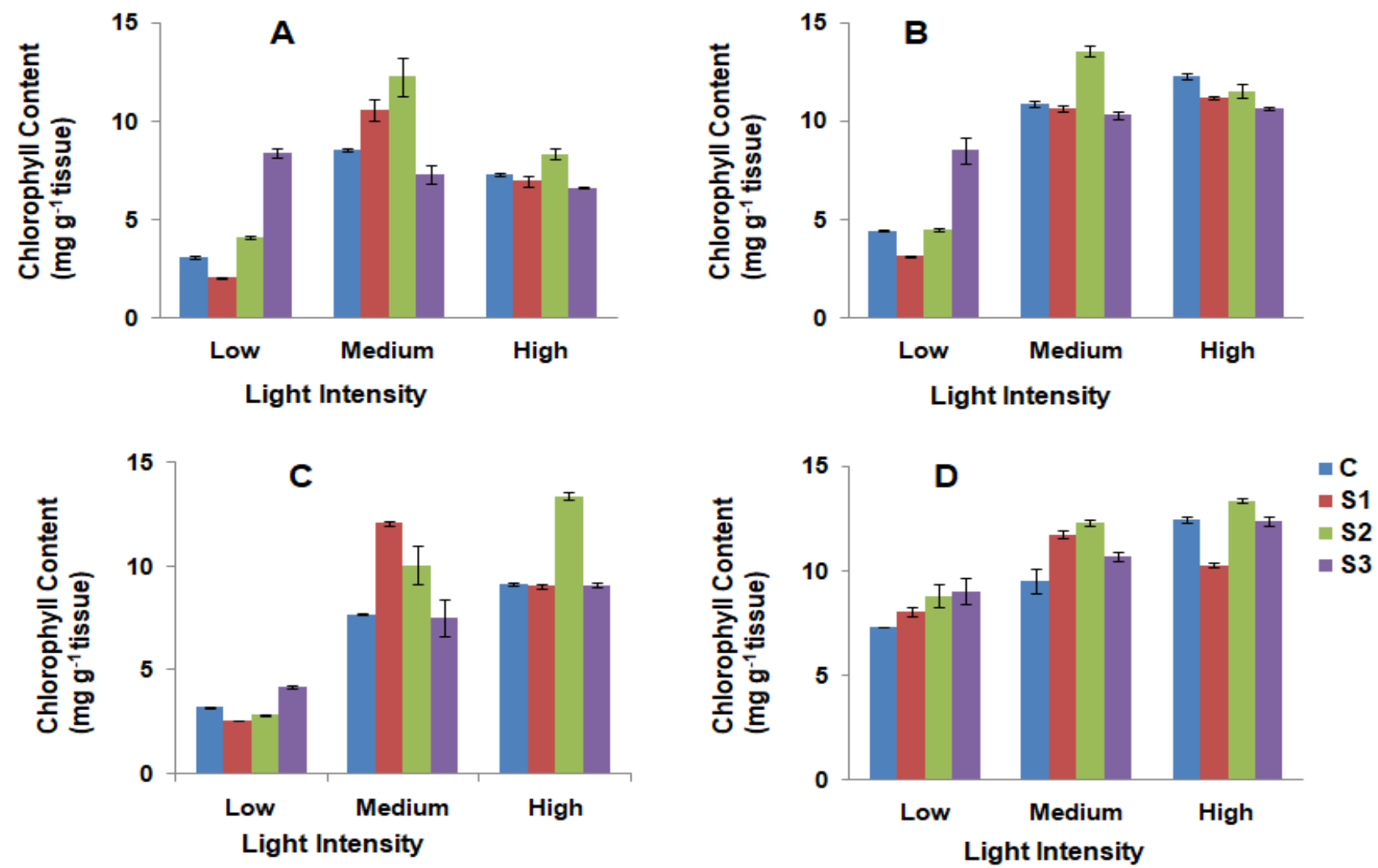

Fig. 10. Changes in chlorophyll content in response to combination of different light intensities [Low $\left(20 \mu \mathrm{moles}^{-2} \mathrm{~s}^{-1}\right) \mathrm{Medium}^{(154}$ $\mu$ moles $\left.\mathrm{m}^{-2} \mathrm{~s}^{-1}\right)$, High $\left(266 \mu\right.$ moles $\left.\mathrm{m}^{-2} \mathrm{~s}^{-1}\right)$ ] and water stress levels [Control (C, 100\%), S1 (50\%), S2 (25\%), S3 (12.5\% )] in 4 rice varieties Bhootmuri (A), CRD 40 (B), IR36 (C) and N22 (D). Vertical bars represent \pm SE 

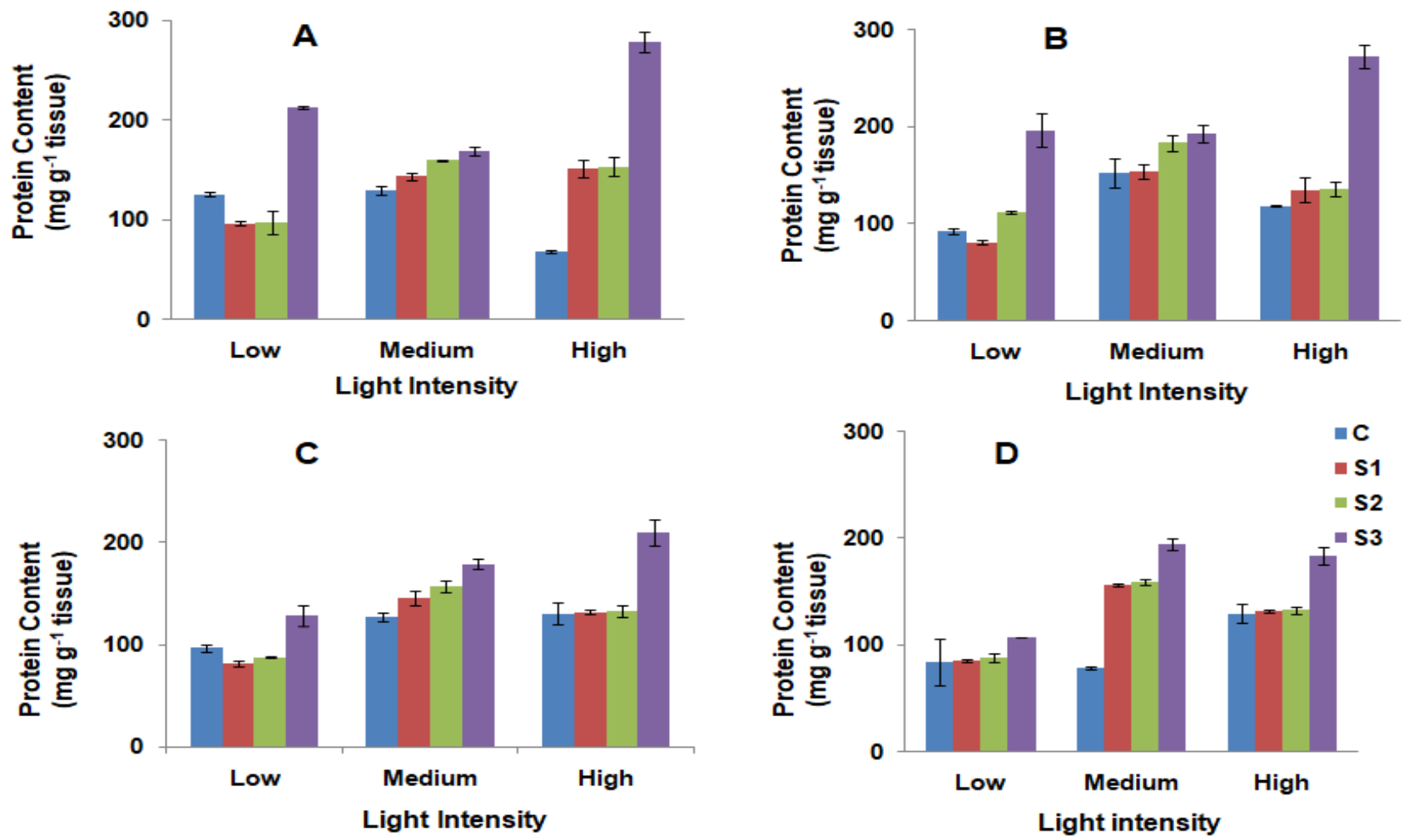

Fig. 11. Changes in protein content in response to combination of different light intensities [Low $\left(20 \mu \mathrm{moles} \mathrm{m}^{-2} \mathrm{~s}^{-1}\right)$ Medium $(154 \mu \mathrm{moles} \mathrm{m}$ $\left.{ }^{2} \mathrm{~s}^{-1}\right)$, High $\left(266 \mu\right.$ moles $\left.\mathrm{m}^{-2} \mathrm{~s}^{-1}\right)$ ] and water stress levels [Control (C, 100\%), S1 (50\%), S2 (25\%), S3 (12.5\% )] in 4 rice varieties - Bhootmuri (A), CRD 40 (B), IR36 (C) and N22 (D). Vertical bars represent \pm SE.
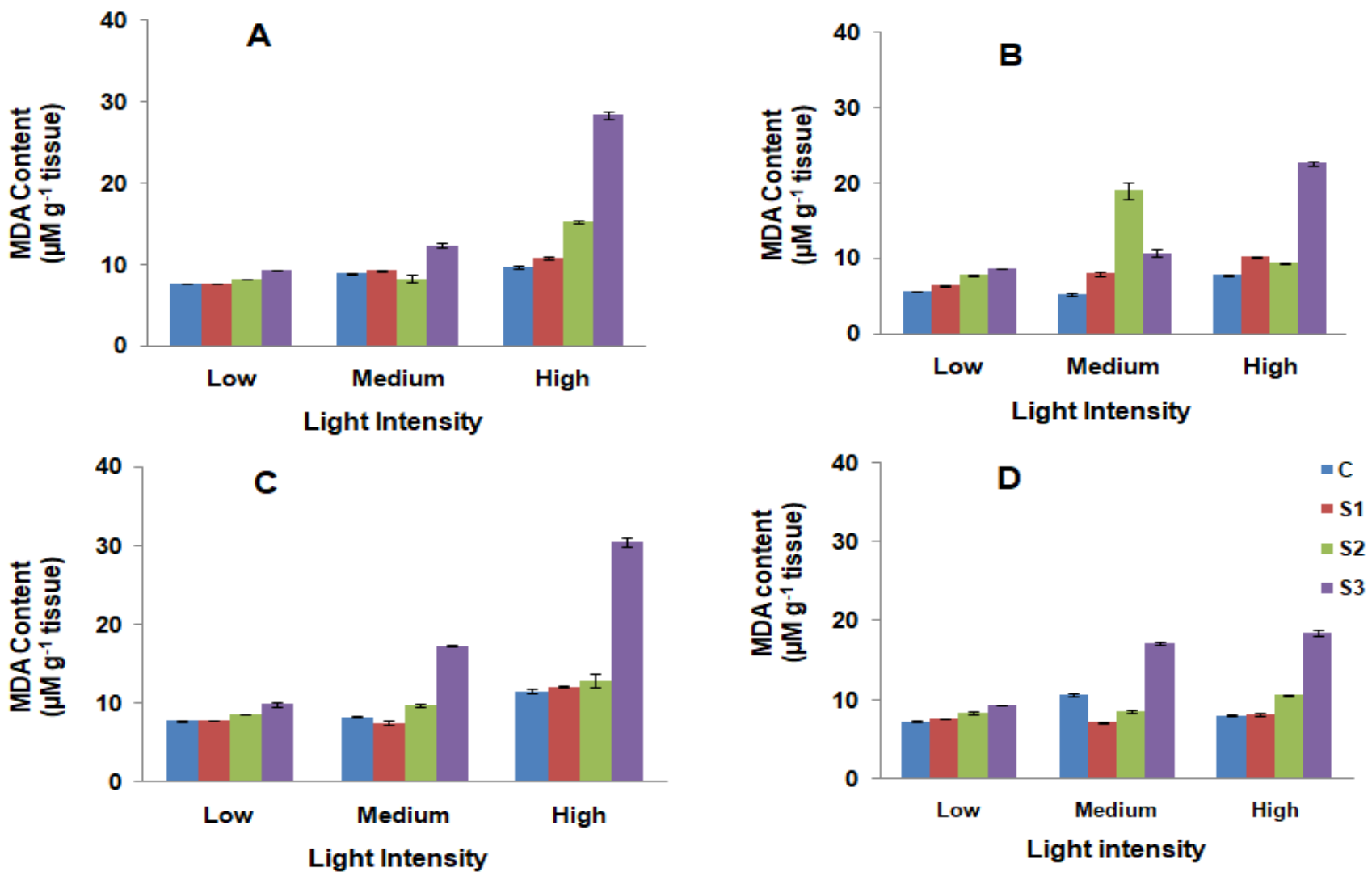

Fig. 12. Changes in malondialdehyde (MDA) content in response to combination of different light intensities [Low $\left(20 \mu \mathrm{moles} \mathrm{m}^{-2} \mathrm{~s}^{-1}\right)$ Medium (154 $\mu$ moles $\left.\mathrm{m}^{-2} \mathrm{~s}^{-1}\right)$, High $\left(266 \mu\right.$ moles $\left.\mathrm{m}^{-2} \mathrm{~s}^{-1}\right)$ ] and water stress levels [Control (C, 100\%), S1 (50\%), S2 (25\%), S3 (12.5\% )] in 4 rice varieties - Bhootmuri (A), CRD 40 (B), IR36 (C) and N22 (D). Vertical bars represent \pm SE. 

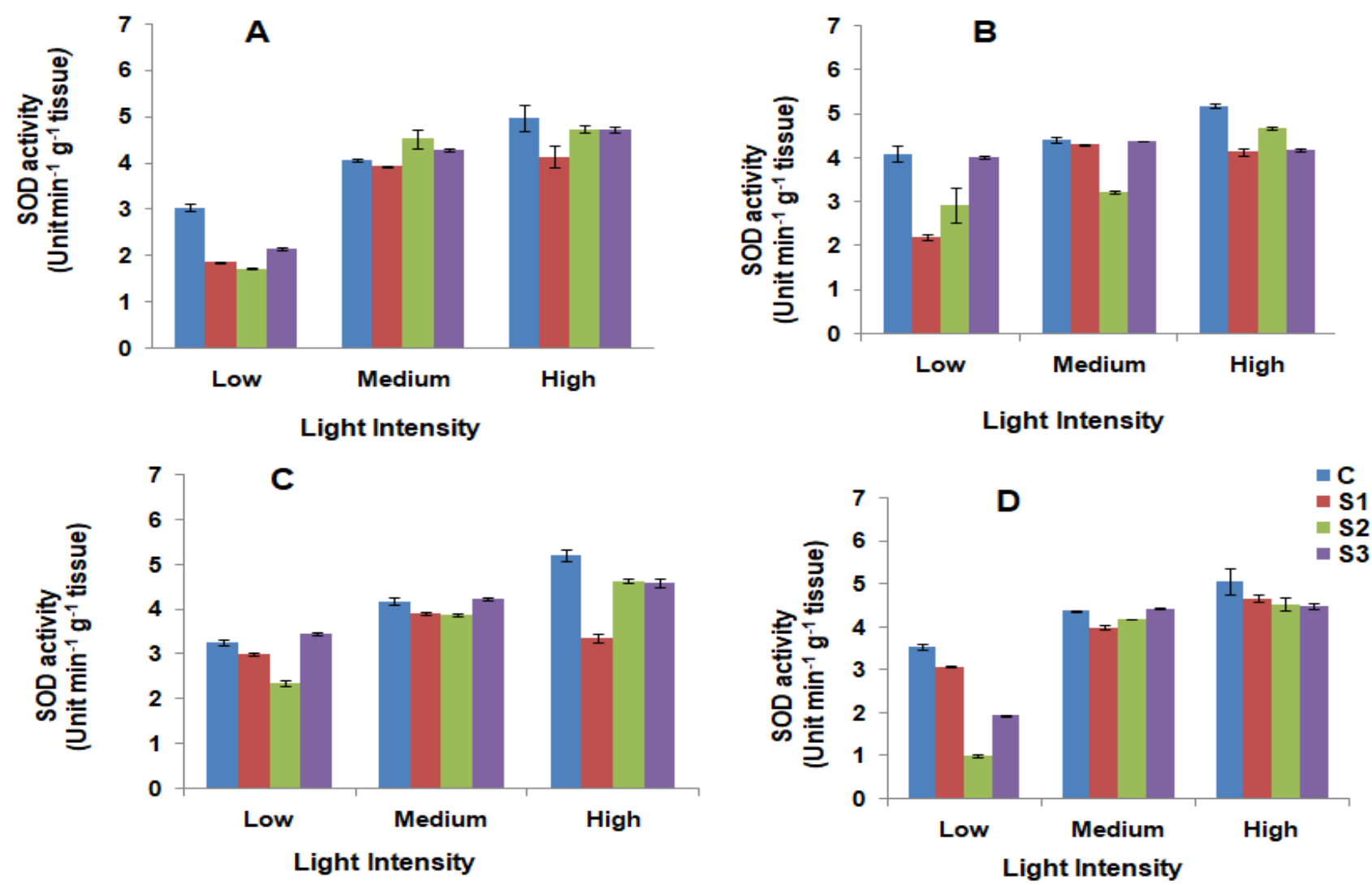

Fig. 13. Superoxide dismutase (SOD) activity in response to combination of different light intensities [Low $\left(20 \mu \mathrm{moles} \mathrm{m}^{-2} \mathrm{~s}^{-1}\right) \mathrm{Medium}^{(154}$ $\mu$ moles $\left.\mathrm{m}^{-2} \mathrm{~s}^{-1}\right)$, High $\left(266 \mu\right.$ moles $\left.\mathrm{m}^{-2} \mathrm{~s}^{-1}\right)$ ] and water stress levels [Control $(\mathrm{C}, 100 \%)$, S1 (50\%), S2 (25\%), S3 (12.5\%)] in 4 rice varieties Bhootmuri (A), CRD 40 (B), IR36 (C) and N22 (D). Vertical bars represent \pm SE.
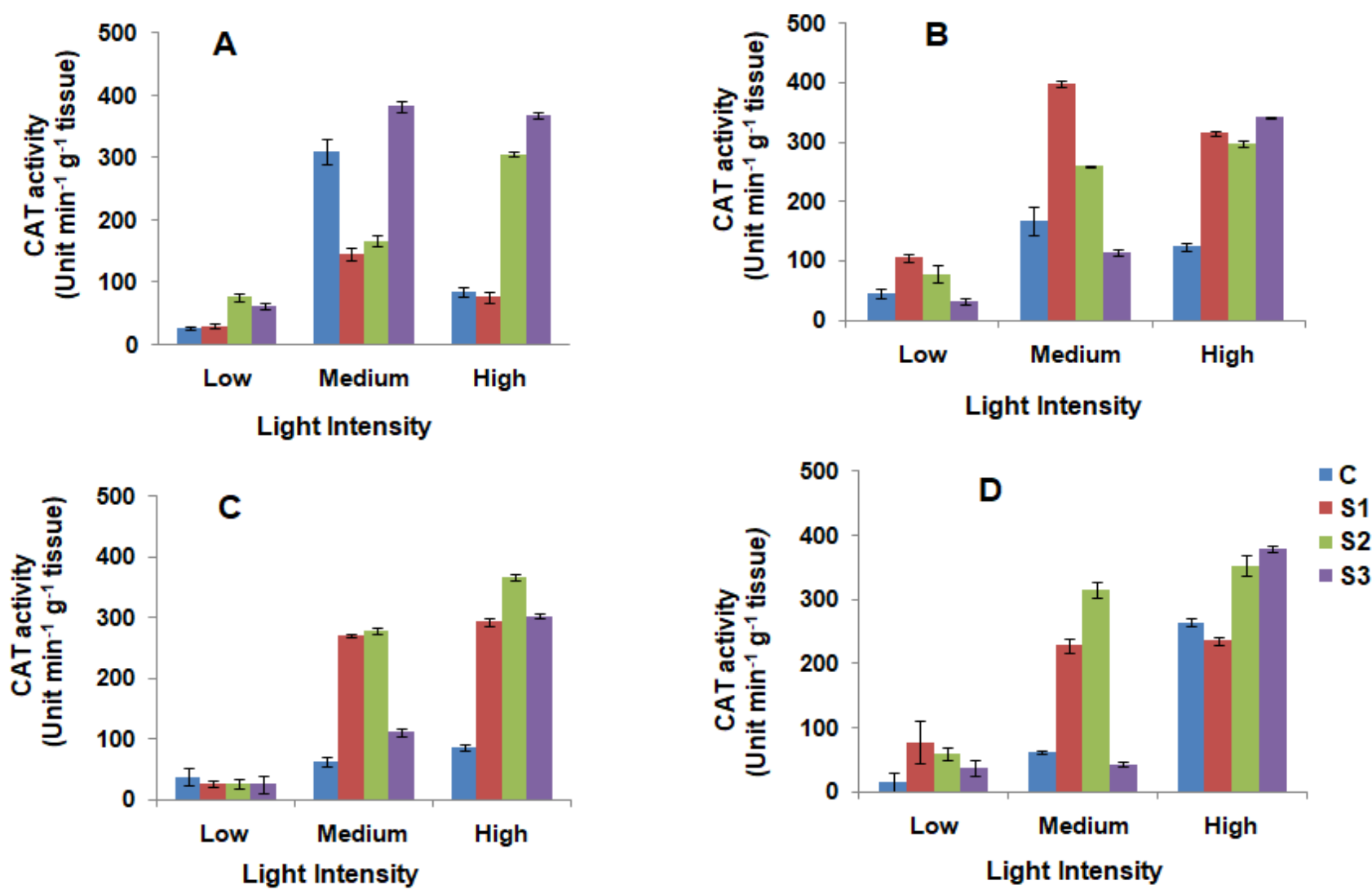

Fig. 14. Catalase (CAT) activity in response to combination of different light intensities [Low $\left(20 \mu \mathrm{moles} \mathrm{m}^{-2} \mathrm{~s}^{-1}\right)$ Medium $\left(154 \mu \mathrm{moles} \mathrm{m}^{-2} \mathrm{~s}\right.$ 1), High (266 $\mu$ moles $\left.\mathrm{m}^{-2} \mathrm{~s}^{-1}\right)$ ] and water stress levels [Control (C, 100\%), S1 (50\%), S2 (25\%), S3 (12.5\% )] in 4 rice varieties - Bhootmuri (A), CRD 40 (B), IR36 (C) and N22 (D). Vertical bars represent \pm SE. 

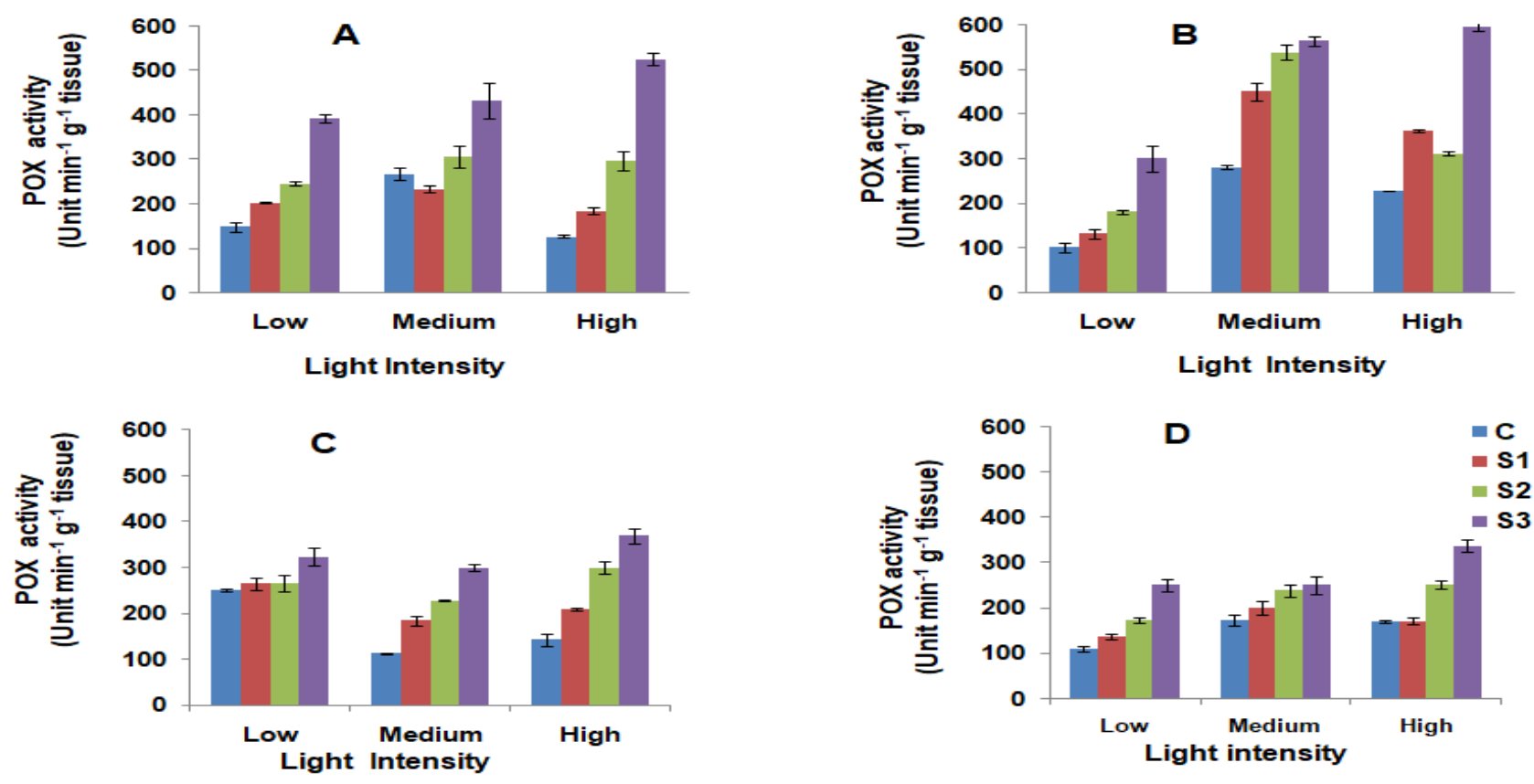

Fig. 15. Peroxidase (POX) activity in response to combination of different light intensities [Low $\left(20 \mu \mathrm{moles} \mathrm{m}^{-2} \mathrm{~s}^{-1}\right) \mathrm{Medium}\left(154 \mu \mathrm{moles} \mathrm{m}^{-2}\right.$ $\left.\mathrm{s}^{-1}\right)$, High $\left(266 \mu\right.$ moles $\left.\mathrm{m}^{-2} \mathrm{~s}^{-1}\right)$ ] and water stress levels [Control (C, 100\%), S1 (50\%), S2 (25\%), S3 (12.5\% )] in 4 rice varieties - Bhootmuri (A), CRD 40 (B), IR36 (C) and N22 (D). Vertical bars represent \pm SE.

POX is an important enzyme of antioxidant system and its activity clearly increased gradually with increasing level of drought (Fig. 15). However, activity did not change much with increasing light intensity at least in case of IR36 and N22 varieties. In all cases the activity was highest at S3 level of water stress at high light. On the other hand, overall activity of APX, like CAT, was lowest at low light in all varieties (Fig. 16). Activity increased considerably with water stress as well as increasing light intensity except in Bhootmuri where overall activity was lower at high light than in medium light.
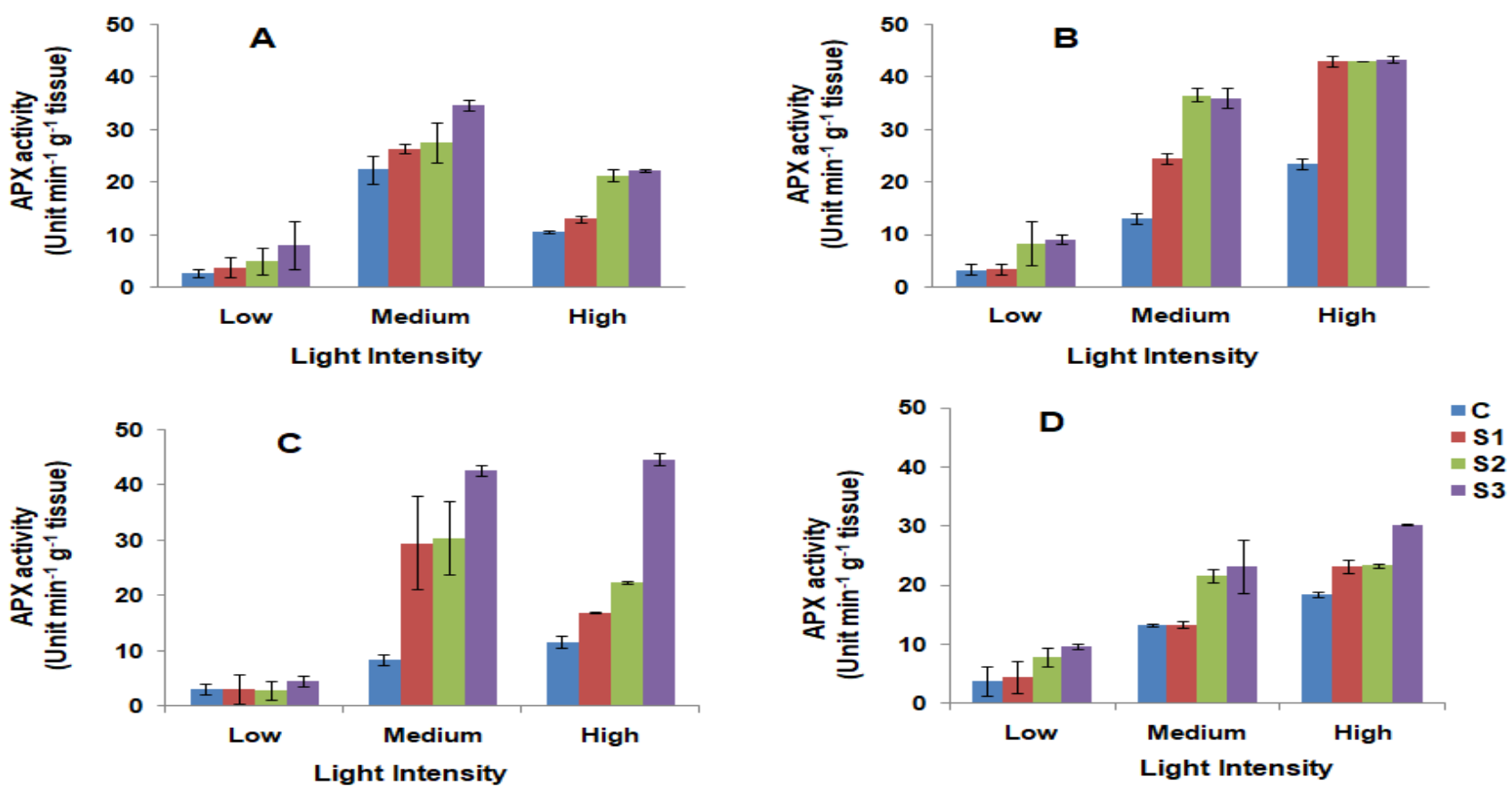

Fig. 16. Ascorbate Peroxidase (APX) activity in response to combination of different light intensities [Low (20 $\left.\mu \mathrm{moles} \mathrm{m}^{-2} \mathrm{~s}^{-1}\right) \mathrm{Medium}(154$ $\mu$ moles $\left.\mathrm{m}^{-2} \mathrm{~s}^{-1}\right)$, High $\left(266 \mu\right.$ moles $\left.\mathrm{m}^{-2} \mathrm{~s}^{-1}\right)$ ] and water stress levels [Control (C, 100\%), S1 (50\%), S2 (25\%), S3 (12.5\% )] in 4 rice varieties Bhootmuri (A), CRD 40 (B), IR36 (C) and N22 (D). Vertical bars represent \pm SE. 

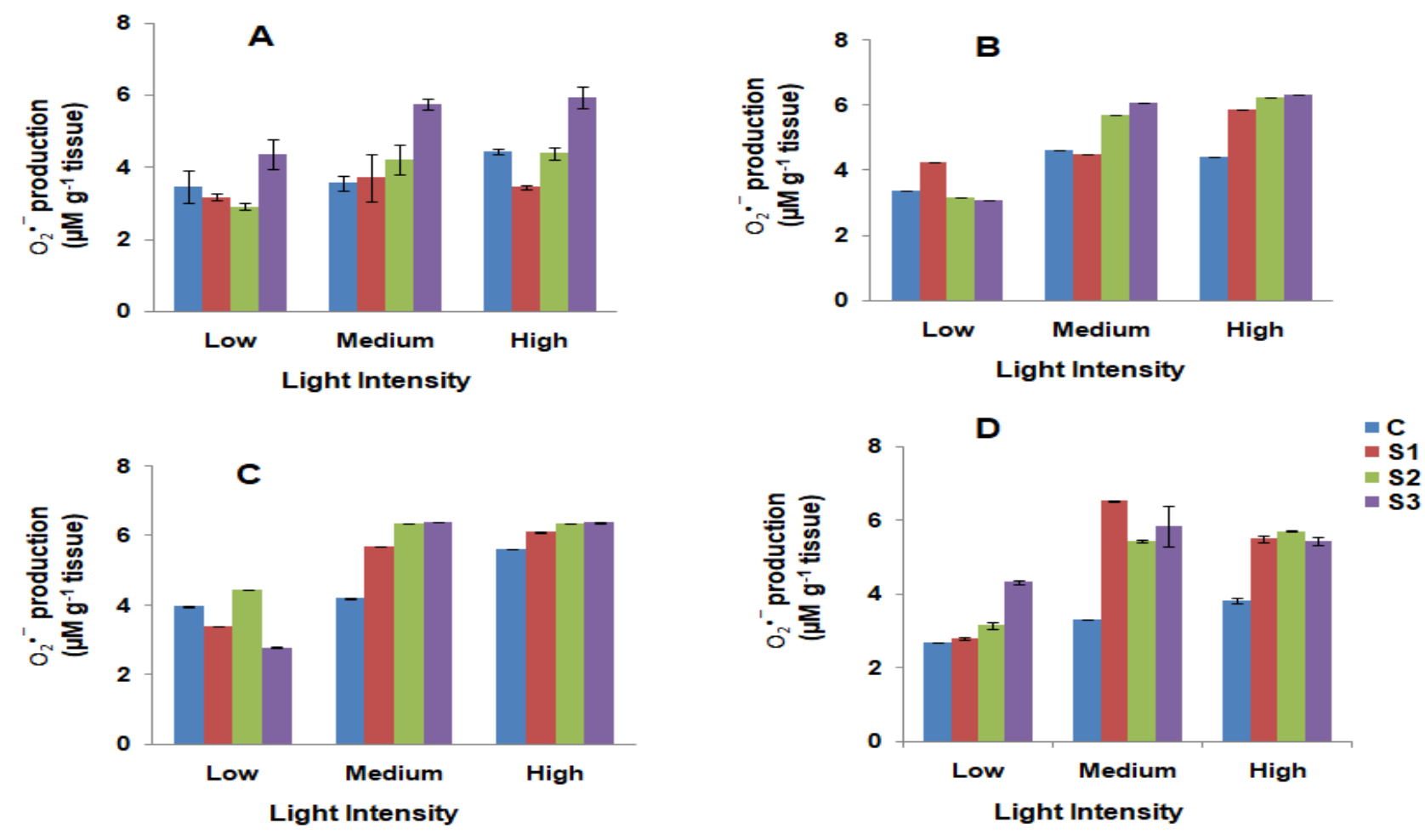

Fig. 17. Production of superoxide $\left(\mathrm{O}_{2}{ }^{-}\right)$in response to combination of different light intensities [Low $\left(20 \mu \mathrm{moles}^{-2} \mathrm{~s}^{-1}\right)$ Medium $(154$ $\mu$ moles $\mathrm{m}^{-2} \mathrm{~s}^{-1}$ ), High $\left(266 \mu\right.$ moles $\left.\mathrm{m}^{-2} \mathrm{~s}^{-1}\right)$ ] and water stress levels [Control (C, 100\%), S1 (50\%), S2 (25\%), S3 (12.5\% )] in 4 rice varieties Bhootmuri (A), CRD 40 (B), IR36 (C) and N22 (D). Vertical bars represent \pm SE.
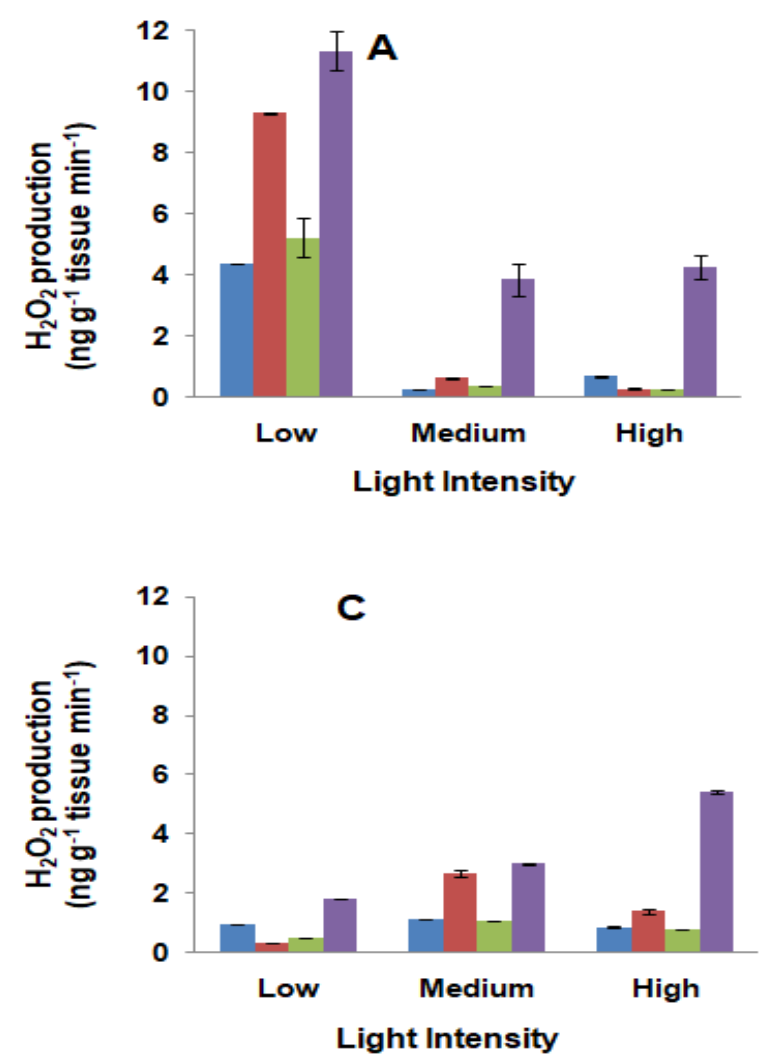
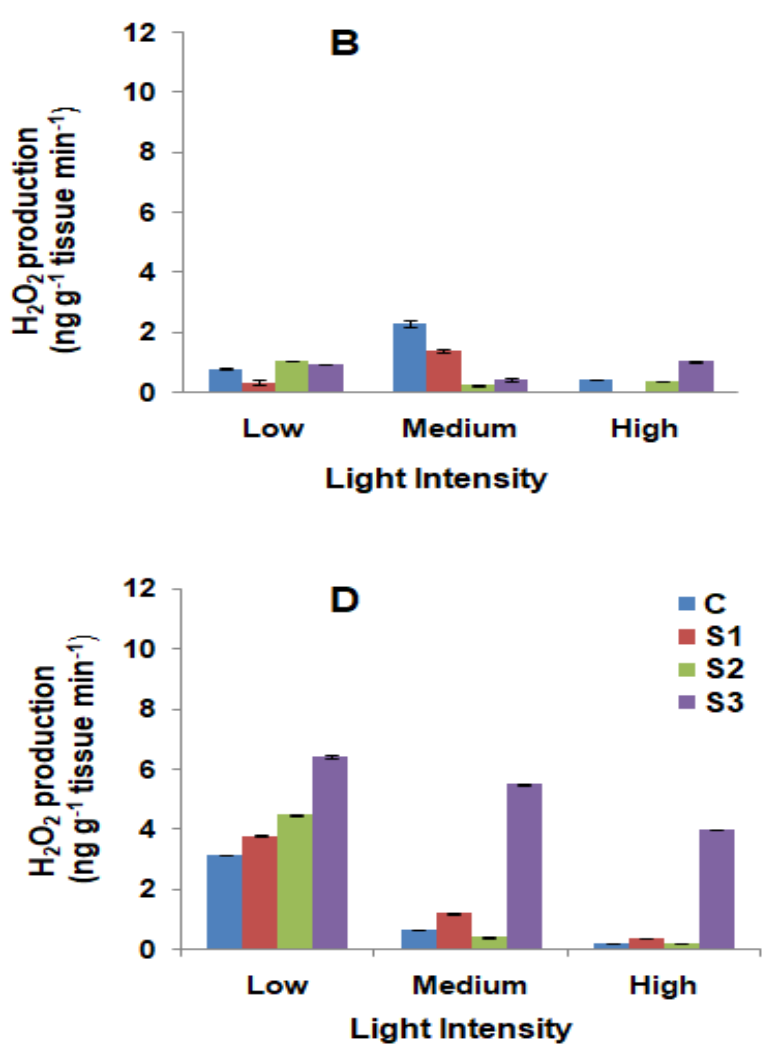

Fig. 18. Production of hydrogen peroxide $\left(\mathrm{H}_{2} \mathrm{O}_{2}\right)$ in response to combination of different light intensities [Low $\left(20 \mu \mathrm{moles} \mathrm{m}^{-2} \mathrm{~s}^{-1}\right) \mathrm{Medium}$ (154 $\mu$ moles $\left.\mathrm{m}^{-2} \mathrm{~s}^{-1}\right)$, High $\left(266 \mu\right.$ moles $\left.\mathrm{m}^{-2} \mathrm{~s}^{-1}\right)$ ] and water stress levels [Control (C, 100\%), S1 (50\%), S2 (25\%), S3 (12.5\%)] in 4 rice varieties - Bhootmuri (A), CRD 40 (B), IR36 (C) and N22 (D). Vertical bars represent \pm SE. 
Total $\mathrm{O}_{2} \cdot-$ production, as a whole, increased almost in all the varieties with increasing level of water stress, being abruptly high in case of S3 plants of Bhootmuri variety (Fig. 17 ). Again the overall level of $\mathrm{O}_{2}{ }^{-}$was low at low light while it was higher at medium and high light intensity in all the varieties. A different scenario was found in case of $\mathrm{H}_{2} \mathrm{O}_{2}$ production (Fig. 18). The $\mathrm{H}_{2} \mathrm{O}_{2}$ level was pretty high at low light in case of Bhootmuri and to some extent in N22 variety, but the level fell down to minimum at higher light intensities except in S3 plants (exposed to highest level of water stress) of Bhootmuri, IR36 and N22 varieties.

\section{Discussion}

Light and water are two vital needs of plants regulating their survival, growth and productivity (29-31) and scarcity or abundance of any of them is injurious to crop plants, thereby limiting crop productivity $(32,33)$. In natural condition, plant is exposed to multiple stresses and their response in combinatorial stress is markedly different from individual stresses (34). Many developed transgenic plants showed tolerance to individual stress but failed to exhibit tolerance in natural condition due to multiple stresses in field condition (14). Combinatorial stresses may be synergistic or antagonistic to each other, such as drought and ozone stress acts synergistically but many other combinations of stress like drought and heat, drought and pathogen, drought and UV, drought and nutrient acts antagonistically (14). Present study with four varieties (Bhootmuri, CRD40, IR36, N22) of rice (Oryza sativa) also showed differential effect when exposed to combination of light and drought stress compared to individual stresses.

Plant growth is the foremost process affected by water stress. Thus, although aboveground shoot portion of the rice varieties increased their height when exposed solely to increasing light, it greatly reduced when light was given in combination with drought stress (Fig. 1-4). This is possibly due to oxidative stress developed through generation of ROS in the chloroplasts by intense light under water stress in spite of a positive role of light in growth. However, root length, unlike shoots, increased in response to light as well as drought and enhancement of root length was more augmented due to synergistic combination of both stresses (Fig. 5-8). Drought stress is already known to have such differential effect, as observed in case of Vigna radiata seedling and also in other plants where shoot growth was prevented but root growth increased under mild water stress, possibly as an adaptive response for searching of new water sources (35-38). Similarly, light may enhance root growth (light escape growth) in search of dark places (39). Studies have shown that light penetrates the soil surface for certain depth depending on texture of soil as well as quality and fluence of light (40). Additionally, light can also penetrate into root through xylem elements using the internal reflectance property of this tissue $(41,42)$. RWC, mainly reflecting water status of shoot, decreased with increasing light and water stress (Fig.
9) indicating an influence of light on water stressinduced lowering of leaf water level. A similar aggravated decline in RWC of rice leaves was also reported under combined water and light stress (43). Desiccation-induced drop in leaf RWC can be correlated with light-induced chloroplast avoidance movement (44) that appears to alleviate photo inhibition usually aggravated under water stress. Interestingly, although there was clear down regulation of photosynthesis in rice with increasing water and light stress (43), in the present study chlorophyll content of rice leaves showed an increase with increasing level of water stress, at least up to medium light intensity, in case of all varieties (Fig. 10). The exact reason for such increase is not clear. Generally drought stress reduces chlorophyll content through the production of ROS in chloroplast, which adversely affect chlorophyll biosynthesis and also cause its destruction (45-48) However, there is one report on chick pea (Cicer arietinum L.) where chlorophyll and carotenoid content increased under mild drought stress, which may be related to a reduced leaf area. It can be a defensive response for plants to minimize the harmful effects of drought stress $(49,50)$. Similarly, in case of protein content also, a similar pattern of increase was noted (Fig. 11). Many genes are expressed in stressful condition to cope up with unfavourable condition and subsequently protein level changes in cell during stress $(51,52)$. In the present study also it may be speculated that increase in protein level may be due to expression of some stress-induced genes.

Major target of most stresses is the cellular membranes that undergo lipid peroxidation caused by stress-induced ROS resulting in production of MDA, which is an indication of stress injury (53). Reports are there about drought-induced lipid peroxidation in few varieties of rice (54). Present study also indicates a higher rate of lipid peroxidation, as reflected in MDA content of leaves, both with increasing level of drought and intensity of light, the effect being synergistic in case of combination of intense light and drought (Fig. 12).

Oxidative state may predominate under any kind of stress due to enhanced production of ROS resulting in cellular damages (55). Both light stress and drought may potentially stimulate ROS generation $(38,39,55,56)$, which is mainly responsible for oxidative degradation of macromolecules (DNA, RNA, proteins, lipids, chlorophylls etc.). Plants tolerant to such stresses are likely to have antioxidant system (antioxidant compounds and enzymes) activated to combat the oxidative degradation by scavenging ROS. Present study revealed that combined stress of light and drought was more effective in stimulating particularly $\mathrm{O}_{2}{ }^{-}$production in four varieties of rice (Fig. 17), which may be ascribed to over excitation of photosystems and disruption of photosynthetic electron transport. Surprisingly, $\mathrm{H}_{2} \mathrm{O}_{2}$ production (Fig. 18), though increased under drought, decreased with light stress except in IR36. Production of $\mathrm{O}_{2}{ }^{--}$was also reported to be higher while that of $\mathrm{H}_{2} \mathrm{O}_{2}$ to be lower under drought stress in some varieties of rice (54, 57). Lowering of $\mathrm{H}_{2} \mathrm{O}_{2}$ with increasing light intensity may be correlated with remarkable 
enhancement in the activities of APX (Fig. 15) and CAT (Fig. 14), both of which are entrusted for scavenging of cellular $\mathrm{H}_{2} \mathrm{O}_{2}$.

As a first line of defence, activity of SOD has been reported to increase under water stress (5459). Interestingly, here SOD activity was found to increase with light intensity, but not with increasing drought, although $\mathrm{H}_{2} \mathrm{O}_{2}$ (supposed to be generated by SOD activity) accumulated significantly particularly under extreme level of water stress, not in response to light (Fig. 18). Possibly $\mathrm{H}_{2} \mathrm{O}_{2}$ might have been produced from some alternative sources. Activities of other antioxidant enzymes viz. CAT (Fig.14), POX (Fig. 15) and APX (Fig. 16) also increased with increasing level of water stress and light intensity and increase was aggravated under combined stress. Again, CAT and APX were found to be more responsive to light. Reports on increased activity of POX and APX in rice under drought stress are there $(54,60)$, although CAT activity was found to decline during drought in case of some rice varieties (54). Here also CAT activity declined at higher levels of stress (below 25\% water status) under lower intensity of light, not at higher intensity. Apparently, moderate water stress induced CAT activity while higher level of water stress caused a decline in activity unless light intensity is not too high, which otherwise augmented CAT activity.

\section{Conclusion}

As a whole, present study reveals that under combination stress of light and drought rice varieties showed a development of light-induced oxidative stress apparently through ROS production as aggravated by drought. Enhanced production of ROS is likely to occur from photosynthetic electron transport system in the irradiated chloroplasts, particularly when there is a spillover of excitation energy or reducing power due to affected photosystems and/or carbon fixation under drought condition. However, a potential defence against stress is also apparent, as reflected in enhanced root growth and antioxidant enzyme activities.

\section{Acknowledgements}

Authors gratefully acknowledge the financial support received from Department of Science and Technology, Govt. of India, under the Indo-Hungarian Joint Project (INT/HUN/P-08/2016) and the Departmental research facilities created under UGCSAP and DST-FIST programmes. Authors are also grateful to Mr. Abhra Chowdhury for the supply of the 'Bhootmuri' rice variety.

\section{Authors' contributions}

RKK and GK envisaged the study. RKK, ND, GK and GG designed the work. AC and TD performed the experiments. All authors participated in the preparation of the manuscript and approved the final manuscript.

\section{Conflict of interests}

The authors declare that they have no conflict of interest.

\section{References}

1. Suzuki N, Rivero RM, Shulaev V, Blumwald E, Mittler R. Abiotic and biotic stress combinations. New Phytol. 2014;203:32-43. https://doi.org/10.1111/nph.12797

2. Mahalingam R. Consideration of combined stress: a crucial paradigm for improving multiple stress tolerance in plants. In: Mahalingam $\mathrm{R}$ (editor). Combined Stresses in Plants. Belin: Springer International Publishing; 2015. p. 1-25. https://doi.org/10.1007/978-3-319-07899-1_1

3. Pandey P, Ramegowda V. Senthil-Kumar M. Shared and unique responses of plants to multiple individual stresses and stress combinations: physiological and molecular mechanisms. Front Plant Sci. 2015a;6:723. https://doi.org/10.3389/ fpls.2015.00723

4. Ramegowda V, Senthil-Kumar M. The interactive effects of simultaneous biotic and abiotic stresses on plants: mechanistic understanding from drought and pathogen combination. J Plant Physiol. 2015;176:47-54. https://doi.org/10.1016/j.jplph.2014.11.008

5. Agarwal S, Grover A. Molecular biology, biotechnology and genomics of flooding-associated low $\mathrm{O}_{2}$ stress response in plants. Crit Rev Plant Sci. 2006;25:1-21. https://doi.org/10.1080/07352680500365232

6. Nakashima K, Yamaguchi-Shinozaki K. Regulons involved in osmotic stress-responsive and cold stress-responsive gene expression in plants. Physiol Plant. 2006;126:62-71. https://doi.org/10.1111/j.1399-3054.2005.00592.x

7. Hirel B, Le Gouis J, Ney B, Gallais A. The challenge of improving nitrogen use efficiency in crop plants towards a more central role for genetic variability and quantitative genetics within integrated approaches. J Exp Bot. 2007;58:2369-87. https://doi.org/10.1093/jxb/erm097

8. Bailey-Serres J, Voesenek LA. Flooding stress: acclimations and genetic diversity. Annu Rev Plant Biol. 2008;59:313-39. https://doi.org/10.1146/annurev.arplant.59.032607. 092752

9. Atkinson NJ, Lilley CJ, Urwin PE. Identification of genes involved in the response to simultaneous biotic and abiotic $\begin{array}{llll}\text { stress. } & \text { Plant } & \text { 2013;162:2028-41. }\end{array}$ https://doi.org/10.1104/pp.113.222372

10. Prasch CM, Sonnewald U. Simultaneous application of heat, drought and virus to Arabidopsis plants reveals significant shifts in signaling networks. Plant Physiol. 2013;162:1849-66. https://doi.org/10.1104/pp.113.22 1044

11. Pandey P, Sinha R, Mysore KS. Senthil-Kumar M. Impact of concurrent drought stress and pathogen infection on plants. In: Mahalingam $\mathrm{R}$ (editor). Combined Stresses in Plants. Belin: Springer International Publishing; 2015b. p. 203-22. https://doi.org/10.1007/978-3-319-07899-1_10

12. Choudhary A, Pandey P, Senthil-Kumar M. Tailored responses to simultaneous drought stress and pathogen infection in plants. In: Hossain MA, Wani SH, Bhattacharjee S, Burritt DJ, Tran L-SP, editors. Drought Stress Tolerance in Plants Vol. 1. Berlin: Springer International Publishing; 2016. p. 427-38. https://doi.org/10.1007/978-3-319-28899-4_18

13. Ramu VS, Paramanantham A, Ramegowda V, Mohan-Raju B, Udayakumar M. Senthil-Kumar M. Transcriptome analysis of sunflower genotypes with contrasting oxidative stress tolerance reveals individual and combined biotic and abiotic stress tolerance mechanisms. PLoS One. 2016;11:e0157522. https://doi.org/10.1371/journal.pone.0157522

14. Mittler R. Abiotic stress, the field environment and stress combination. Trends Plant Sci. 2006;11:15-19. https://doi.org/10.1016/j.tplants.2005.11.002 
15. Lauteri M, Haworth M, Serraj R, Monteverdi MC, Centritto M. Photosynthetic diffusional constraints affect yield in drought stressed rice cultivars during flowering. PLoS One. 2014;9:e109054. https://doi.org/10.1371/journal.pone.0109054

16. Heyne EG, Brunson AM. Genetic studies of heat and drought tolerance in maize J Am Soc Agro. 1940;32:803-14. https://doi.org/10.2134/agronj1940.0002196200320010000 9x

17. Moffat AS. Finding new ways to protect drought-stricken plants. $\quad$ Science. 2002;296:1226-29. https://doi.org/10.1126/science.296.5571.1226

18. Weatherley PE. Studies in the water relations of the cotton plant I. The field measurement of water deficits in leaves. New Phytol. 1950;49:81-97. https://doi.org/10.1111/j.14698137.1950.tb05146.x

19. Arnon DI. Copper enzymes in isolated chloroplasts Polyphenoloxidase in Beta vulgaris. Plant Physiol. 1949;24:115. https://doi.org/10.1104/pp.24.1.1

20. Lowry OH, Rosebrough NJ, Farr AL, Randall RJ. Protein measurement with the Folin phenol reagent. J Biol Chem. 1951;193:265-75. https://doi.org/10.1016/S0021-9258(19)524516

21. Heath RL, Packer L. Photoperoxidation in isolated chloroplasts: I. Kinetics and stoichiometry of fatty acid peroxidation. Arch Biochem Biophys. 1968;125:189-98. https://doi.org/10.1016/0003-9861(68)90654-1

22. Giannopolitis CN, Ries SK. Superoxide dismutases: I. Occurrence in higher plants. Plant Physiol. 1977;59:309-14. https://doi.org/10.1104/pp.59.2.309

23. Biswas AK, Choudhuri MA. Differential behaviour of the flag leaf of intact rice plant during ageing. Biochem Physiol Pflanz. 1978;173:220-28. https://doi.org/10.1016/ S00153796(17)30485-7

24. Kar RK, Choudhuri MA. Possible mechanisms of light-induced chlorophyll degradation in senescing leaves of Hydrilla verticillata. Physiol 1987;70:729-34. https://doi.org/10.1111/j.1399-3054.1987.tb04331.x

25. Nakano Y, Asada K. Hydrogen peroxide is scavenged by ascorbate-specific peroxidase in spinach chloroplasts. Plant Cell Physiol. 1981;22:867-80.

26. Fick GN, Qualset CO. Genetic control of endosperm amylase activity and gibberellic acid responses in standard-heigh and short-statured wheats. Proc Natl Acad Sci USA. 1975;72:892-95._https://doi.org/10.1073/pnas.72.3.892

27. Misra HP, Fridovich I. The role of superoxide anion in the autoxidation of epinephrine and a simple assay for superoxide dismutase. J Biol Chem. 1972;247:3170-75. https://doi.org/10.1016/S0021-9258(19)45228-9

28. Gay C, Gebicki JM. A critical evaluation of the effect of sorbitol on the ferric-xylenol orange hydroperoxide assay. Analyt Biochem. 2000;284:217-20. https://doi.org/ 10.1006/abio.2000.4696

29. McElrone AJ, Choat B, Gambetta GA, Brodersen CR. Water Uptake and Transport in Vascular Plants. Nature Education Knowledge. 2013;4(5):6.

30. Bayat L, Arab M, Aliniaeifard S, Seif M, Lastochkina O and Li T. Effects of growth under different light spectra on the subsequent high light tolerance in rose plants. AoB Plants. 2018;10:ply052. https://doi.org/10.1093/aobpla/ply052

31. Klem K, Gargallo-Garriga A, Rattanapichai W, Oravec M, Holub P, Vesela B, Sardans J, Penuelas J, Urban O. Distinct morphological, physiological and biochemical responses to light quality in barley leaves and roots. Front Plant Sci. 2019;10:1026. https://doi.org/10.3389/fpls.2019.01026

32. Fahad S, Bajwa AA, Nazir U, Anjum SA, Farooq A, Zohaib A, Sadia S, Nasim W, Adkins S, Saud S, Ihsan MZ, Alharby H, Wu C, Wang D, Huan J. Crop production under drought and heat stress: Plant responses and management options. Front Plant Sci. 2017;8:1147.https://doi.org/10.3389/fpls.2017.01147

33. Francini A, Sebastiani L. Abiotic stress effects on performance of horticultural crops. Horticulturae. 2019;5:67. https://doi.org/10.3390/horticulturae5040067
34. Pandey P, Irulappan V, Bagavathiannan MV and SenthilKumar M. Impact of combined abiotic and biotic stresses on plant growth and avenues for crop improvement by exploiting physio-morphological traits. Front Plant Sci. 2017;8:537. https://doi.org/10.3389/fpls.2017.00537

35. Fenta BA, Beebe SE, Kunert KJ, Burridge JD, Barlow KM, Lynch JP, Foyer $\mathrm{CH}$. Field phenotyping of soybean roots for drought stress tolerance. Agronomy. 2014;4:418-35. https://doi.org/10.3390/agronomy4030418

36. Taiz L, Zeiger E, Moller IM, Murphy A. Plant Physiology and Development. 6th ed. USA: Sinauer Associates; 2015. p. 561.

37. Kwon MY, Woo SY. Plant's responses to drought and shade environments. Afr J Biotechnol. 2016;15(2):29-31. https://doi.org/10.5897/AJB2015.15017

38. Das S, Kar RK. Reactive oxygen species mediated promotion of root growth under mild water stress during early seedling stage of Vigna radiata (L.) Wilczek. J Plant Growth Regul. 2017;36:338-47._https://doi.org/10.1007/s00344-016-9643-9

39. Yokawa K, Kagenishi T, Kawano T, Mancuso S, Baluška F. Illumination of Arabidopsis roots induces immediate burst of ROS production. Plant Signal Behav. 2011;6:1460-64. https://doi.org/10.4161/psb.6.10.18165

40. Mo M, Yokawa K, Wan Y, Baluska F. How and why do root apices sense light under the soil surface? Front Plant Sci. 2015; https://doi.org/10.3389/fpls.2015.00775

41. Mandoli DF and Briggs WR. Optical properties of etiolated plant tissues, Proc Natl Acad Sci USA. 1982;79:2902-06.

42. Galen C, Rabenold JJ, Liscum E. Light-sensing in roots. Plant Signal Behav. 2007;2:106-08. https://doi.org/10.4161/psb.2.2.3638

43. Zhou Y, Lam HM, Zhang J. Inhibition of photosynthesis and energy dissipation induced by water and high light stresses in rice. J Exp Bot. 2007;58:1207-17. https://doi.org/10.1093/jxb/erl291

44. Nauš J, Šmecko S, Špundová M. Chloroplast avoidance movement as a sensitive indicator of relative water content during leaf desiccation in the dark. Photosynth Res. 2016;129(2):217-25._https://doi.org/10.1007/s11120-016-0291-5

45. Aarti PD, Tanaka R, Tanaka A. Effects of oxidative stress on chlorophyll biosynthesis in cucumber (Cucumis sativus) cotyledons. Physiol Plant. 2006;128:186-97. https://doi.org/10.1111/j.1399-3054.2006.00720.x

46. Maria H. Drought stress and reactive oxygen species. Production, scavenging and signalling. Plant Signal Behav. 2008;3(3):156-65. https://doi.org/10.4161/psb.3.3.5536

47. Lum MS, Hanafi MM, Rafii YM, Akmar ASN. Effect of drought stress on growth, proline and antioxidant enzyme activities of upland rice. J Anim Plant Sci. 2014;24(5):1487-93.

48. Ibrahim EK, Hashem HA, Abou Ali RM, Hassanein AA. Comparative physiological study on six Egyptian rice cultivars differing in their drought stress tolerance. Acta Scientific Agriculture. 2019;3(3):44-52.

49. Farooq M, Wahid A, Kobayashi N, Fujita D, Basra SMA. Plant drought stress: effects, mechanisms and management. Agron Sustain Dev. 2009;29:153-88. https://doi.org/ 10.1051/agro:2008021

50. Rahbarian R, Khavari-Nejad R, Ganjeali A, Bagheri A, Najafi F. Drought stress effects on photosynthesis, chlorophyll fluorescence and water relations in tolerant and susceptible chickpea (Cicer arietinum L.) genotypes. Acta, Biologica

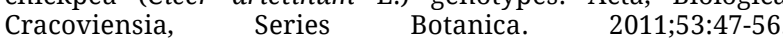
https://doi.org/10.2478/v10182-011-0007-2

51. Riccardi F, Gazeau P, Vienne D, Zivy M. Protein changes in response to progressive water deficit in maize. Plant Physiol. 1998;117:1253-63. https://doi.org/10.1104/pp.117.4.1253

52. Merewitz EB, Gianfagna T, Huang B. Protein accumulation in leaves and roots associated with improved drought tolerance in creeping bentgrass expressing an ipt gene for cytokinin synthesis. J Exp Bot. 2011;62:5311-33. https://doi.org/10.1093/jxb/err166

53. Anjum SA, Xie XY, Wang LC, Saleem MF, Man C, Lei W. Morphological, physiological and biochemical responses of 
plants to drought stress. Afr J Agric Res. 2011;6(9):2026-32. https://doi.org/10.5897/AJAR10.027

54. Sharma P, Dubey RS. Drought induces oxidative stress and enhances the activities of antioxidant enzymes in growing rice seedlings. Plant Growth Regul. 2005;46:209-21. https://doi.org/10.1007/s10725-005-0002-2

55. Kar RK. Plant responses to water stress: role of reactive oxygen species. Plant Signal Behav. 2011;6:1741-45. https://doi.org/10.4161/psb.6.11.17729

56. Gill SS, Tuteja N. Reactive oxygen species and antioxidant machinery in abiotic stress tolerance in crop plants. Plan Physiol Biochem. 2010;48:909-30. https://doi.org/10.1016/j.plaphy.2010.08.016

57. Sahoo S, Saha B, Awasthi JP, Omisun T, Borgohain P, Hussain S, Panigrahi J, Panda S K. Physiological introspection into differential drought tolerance in rice cultivars of North East India. Acta Physiol Plant. 2019;41:53. https://doi.org/10.1007/s11738-019-2841-x

58. Das S, Kar RK. Abscisic acid mediated differential growth responses of root and shoot of Vigna radiata (L.) Wilczek seedlings under water stress. Plant Physiol Biochem. 2018;123:213-21. https://doi.org/10.1016/j.plaphy.2017.12.016

59. Sahu M, Kar RK. Possible interaction of ROS, antioxidants and ABA to survive osmotic stress upon acclimation in Vigna radiata (L). Wilczek seedlings. Plant Physiol Biochem. 2018;132:415-23. https://doi.org/10.1016/j.plaphy.2018.09.034
60. Kamarudin ZS, Yusop MR, Mohamed MTM, Ismail MR and Harun AR. Growth performance and antioxidant enzyme activities of advanced mutant rice genotypes under drought stress condition. Agronomy. 2018;8:279. https://doi.org/ 10.3390/agronomy8120279

\section{Additional information}

Peer review information: Plant Science Today thanks Sectional Editor and the other anonymous reviewers for their contribution to the peer review of this work.

Reprints and permissions information is available at https://horizonepublishing.com/journals/index.php/PST/open_access_policy

Publisher's Note: Horizon e-Publishing Group remains neutral with regard to jurisdictional claims in published maps and institutional affiliations.

To cite this article: Chatterjee A, Dey T, Galiba G, Kocsy G, Dey N, Kar R K. Effect of combination of light and drought stress on physiology and oxidative metabolism of rice plants. Plant Science Today. 2021;8(4):762-777 https://doi.org/10.14719/pst.2021.8.4.1245

Plant Science Today, published by Horizon e-Publishing Group, is covered by Scopus, Web of Science, BIOSIS Previews, Clarivate Analytics, etc. See https://horizonepublishing.com/journals/index.php/PST/indexing_abstracting 